

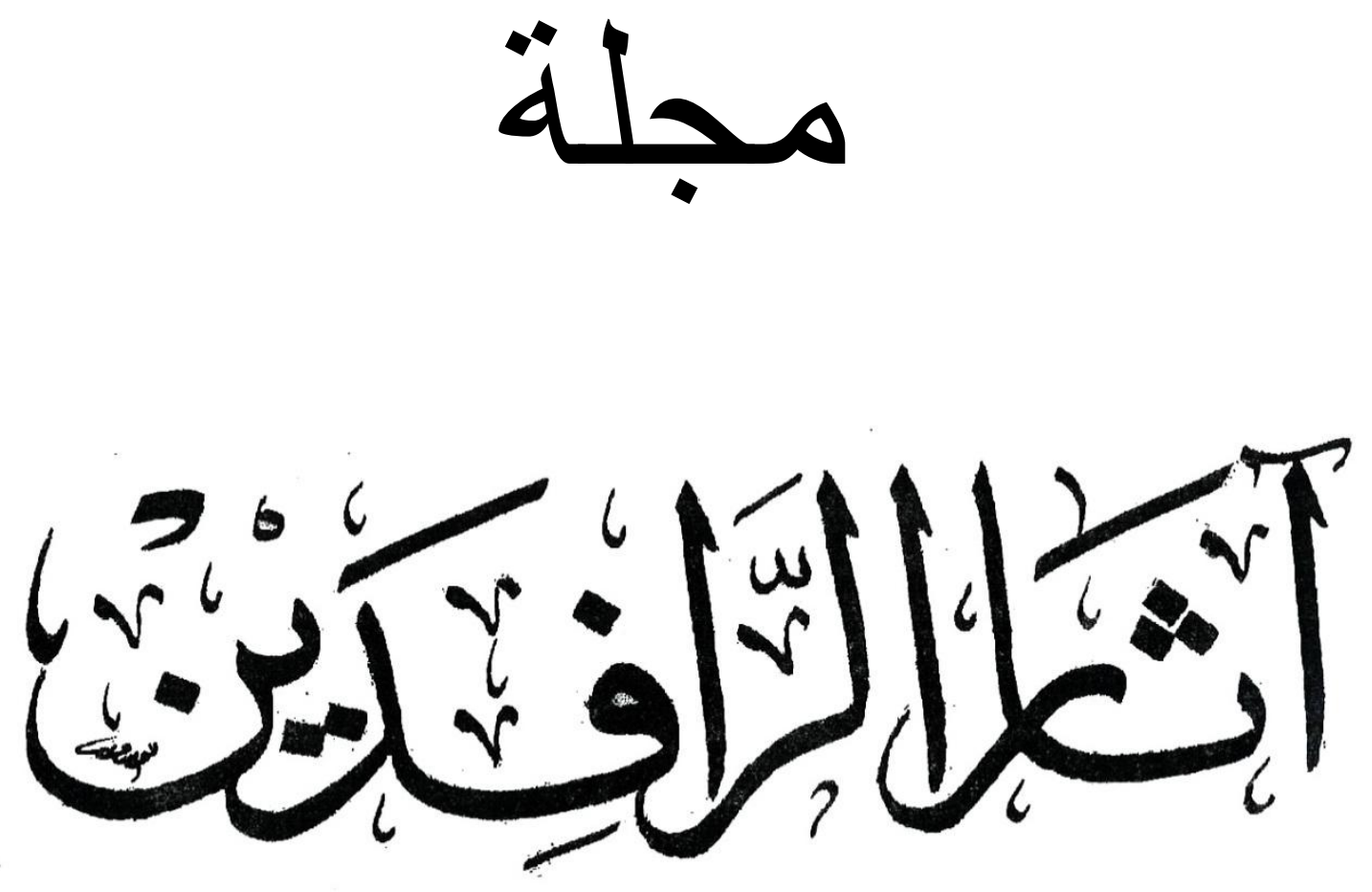

هجلة علمية همكمة تبحث في آثار العراق و الشرق الأدنى القديم تصدر عن كلية الآثار في جاهعة الموصل

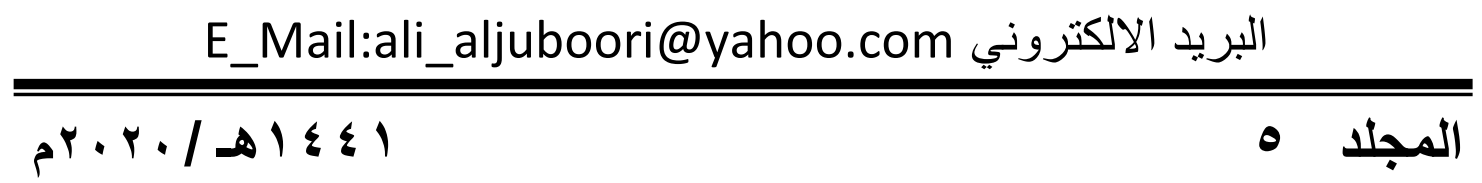



رقم الإِيداع في دار الكتب و الوثائق ببغداد

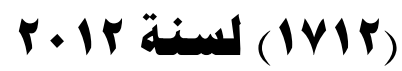





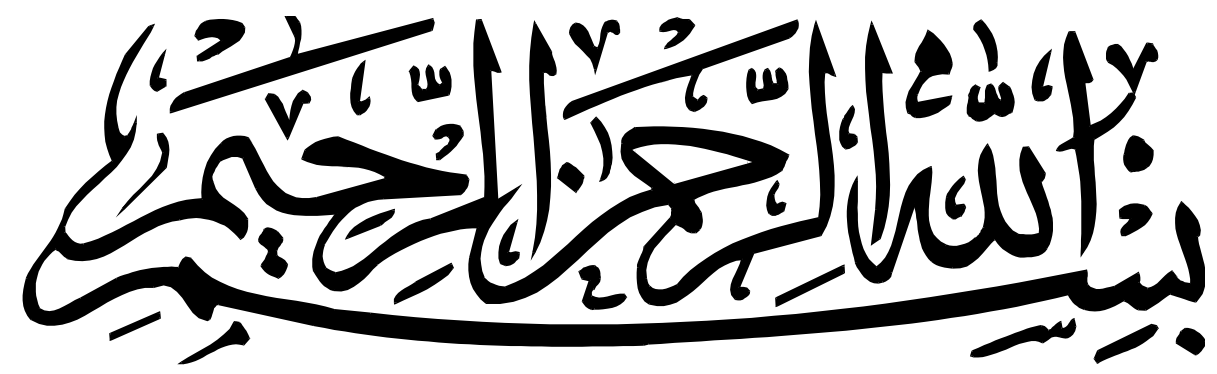





$$
\text { أ.د. علي ياسية التمرير الجبوري }
$$

$$
\begin{aligned}
& \text { أ.م.د. فيان هوفق رشيد النعيمي } \\
& \text { أ.د. صفوان ساهي سعيد الرفاعي } \\
& \text { سكرتير التصرير } \\
& \text { نائب رئيس التمرير }
\end{aligned}
$$

الأوضاs

أ.د. شعلان كاهل اسماعيل

أ.د. عاهر عبدالاله نجم الجُميلي

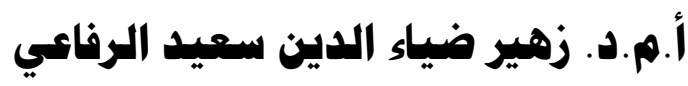

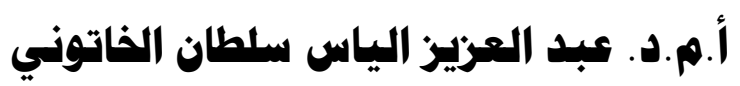

$$
\begin{aligned}
& \text { الخبير الاغوي } \\
& \text { أ.م.د. همن يميى هممد العبادي } \\
& \text { كلية الآداب - جاهعة الموصل } \\
& \text { الهيأة الاستشارية }
\end{aligned}
$$

جامعة الموصل

جاهمة بغداد

جاهعة الموصل

جامعة الموصل

جاهمة الموصل

جاهعة القادسية

جاهعة الكوفة 



\section{قواعد النشر في المبلة}

• يشترط أن يكون البحث ضهن الاختصاصات التي تُعنى بها المجلة • يشترط على الباحث الالتزام بالموضوعية و المنهج العلمي في البحث و التحليل ،و أن يلتزه بشروط البحث العلمي هن حيث التبويب و استعمال الهواهش و الإشارة إلى المصادر و المراجع وفق طريقة هنهجية و احدة ،و في

$$
\text { آخر البحث }
$$

• يشترط على الباحث هراعاة الجوانب الشكلية و الاهتهام بسلاهة لغة البحث هن الأخطاء اللغوية و المطبعية

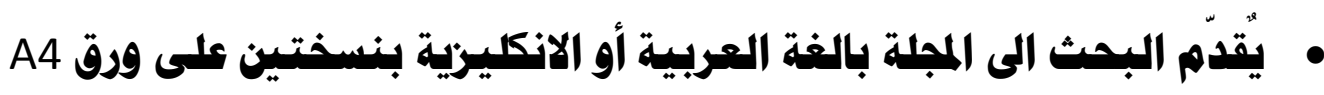
• يرافق البحث في أوله هلخص" باللغة الانكليزية على أن لا يريد عدد كلماته

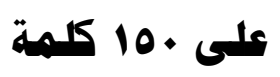

• يشترط أن لا يكون البحث قد نشر او قبل للنشر في أيّة دورية علمية داخل

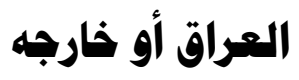

• يشترط على الباحث أن لا تتجاوز عدد صفحات بثه عن ro صفحة • يشترط في البحث أن تكون المشاهد و الأشكال الفنية المرافقة له عالية الجودة • أصول البحث المقدهة إلى البلة لا ترد أو تُسترجع سواء نشرت أم لم تنشر • تعتمد المجلة هبدأ التمويل الذاتي وتهدد أجور النشر في ضوء الأسعار السائدة 

ثبت المحتويات

\begin{tabular}{|c|c|c|}
\hline 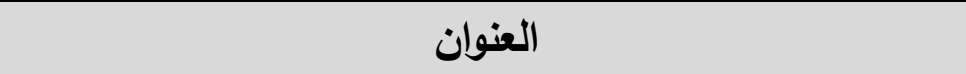 & 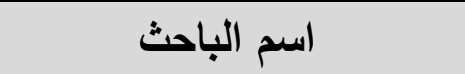 & الصفحة \\
\hline توطئة & أ.د. علي ياسين الجبوري & 1 \\
\hline نعي - الراحل الأستاذ الدكتور عبد القادر عبد الجبار مصطفى & أ.د. جابر خليل إبراهيم & r \\
\hline ملحمة كلكامش : الاصالة والتأثثر & أ.د. علي ياسين الجبوري & $r r-V$ \\
\hline نصوصُّ اقتصاديةٌ غيرُ منشورةٍ مِنْ عَهْرِ الملكِ شو - سين & أ. خالد سالم اسماعيل & 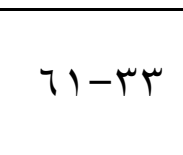 \\
\hline معالجة رُقُقُم طينية من منحف السليمانية & أ. خالد سالم اسماعيل & $V V-7 r$ \\
\hline تسويق المنتجات الزراعية بين مدن العراق القديم & أ.د. حسين ظاهر حمود & $90-\vee 9$ \\
\hline 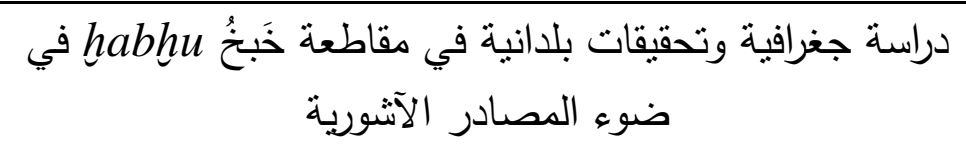 & أ. د. د. عامر عبد الله الجميلي & $1 K V-9 V$ \\
\hline مظاهر الحرية والاستبداد في نظم الإدارة المركزية في المملكة & أ.د. صفوان سامي سعيد & $109-1 Y 9$ \\
\hline شخصية الملوك الآشوريين وصفاتهم القيادية & عفراء يحيى قاسم أ.د. صفوان سامي سعيد & $19 \cdot-171$ \\
\hline تاريخ التتقيبات الأثريّة في مدينة نينوى & د. د. عبد الستار أحمد حسين & Y) $\leq-191$ \\
\hline 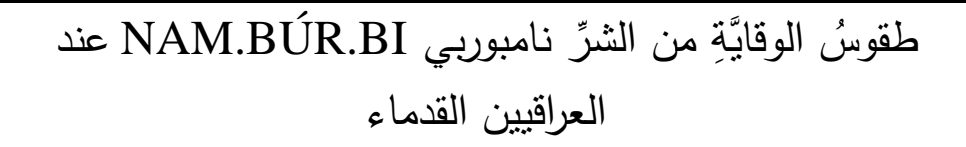 & د. نبيل خالد شيت سليمان & $r Y 9-Y 10$ \\
\hline الزواج بين النص المسماري والقرآني -دراسة مقارنة & أ. م. نسرين أحمد عبد يحيى الجبوري & YTV-rTI \\
\hline عقود قرض غبر منشورة من مدينة لاكابا من العصر البابلي & م. آرام جلال حسن الهموندي & YAN-Yrq \\
\hline الثـــكل والإعجام في الخطّ العربيّ & م. وسن عبد المطلب حسن & $r \cdot V-r \wedge q$ \\
\hline تل الحويش (مدينة أوباسي؟) في الكتابات المسمارية والتحريات & م. غسان صالح الحميضة & $r r \leqslant-r \cdot q$ \\
\hline المواقعُ الجغرافيةُُ لانتشارِ فخارِ العُبيد الثمالي & م.م. دريد سليم بولس & 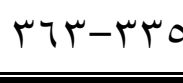 \\
\hline
\end{tabular}





\section{بسم الله الرحمن الرحيم \\ توطئة}

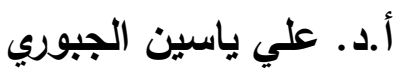

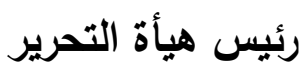

يصدر العدد الخامس من مجلة آثار الرافين الثابع لكلية الآثار - جامعة الموصل

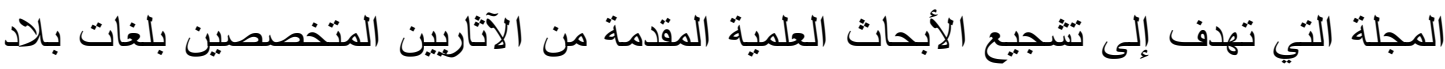

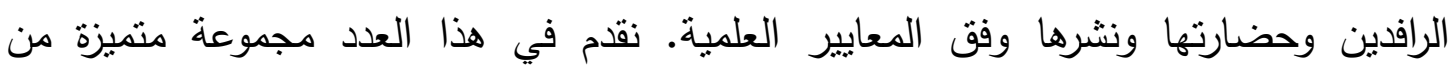

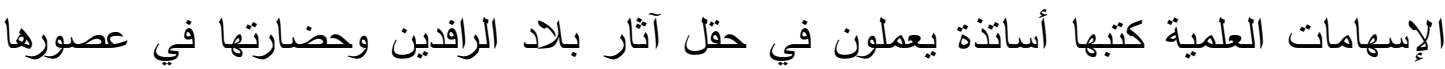

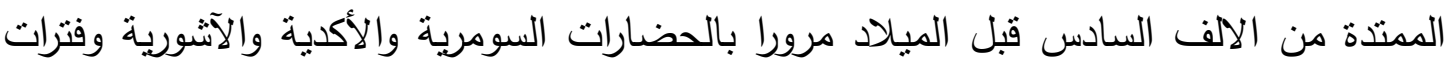

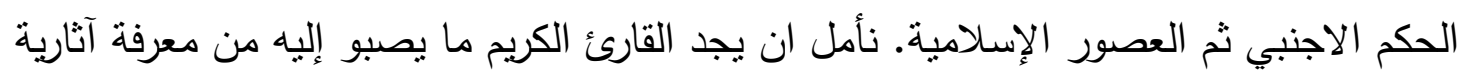

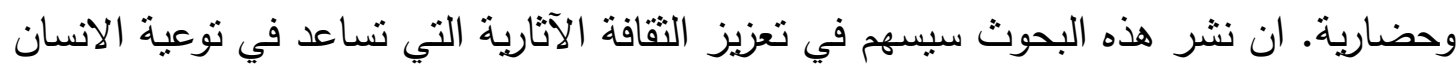

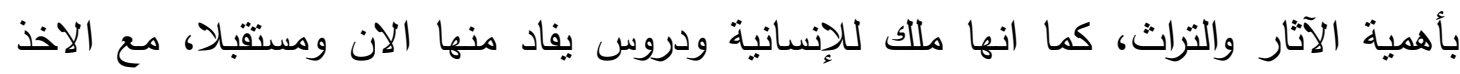

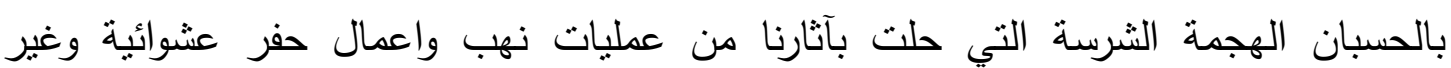

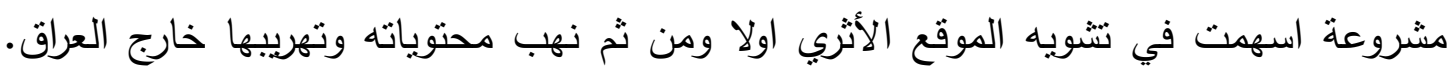

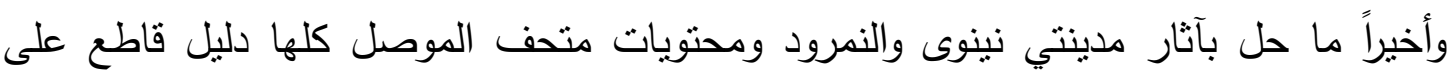

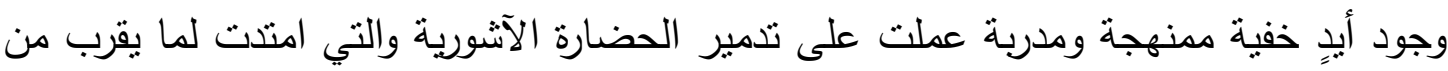
( ب.... T الف سنة قبل الميلاد.

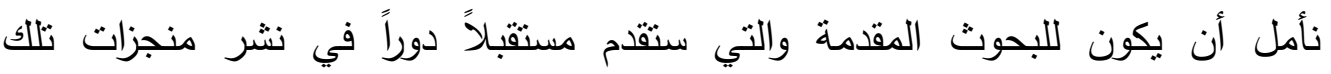

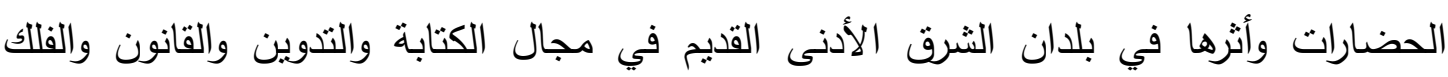
والتجيم والهندسة والرياضيات والطب والآداب بكل مجالاتئها.

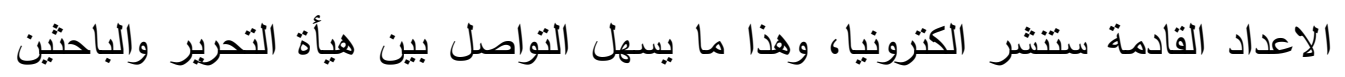
إن شاء الله. وستزود المجلة الباحثين بموقعها الجديد وكيفية التقديم اليها.

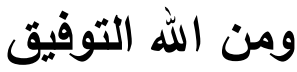





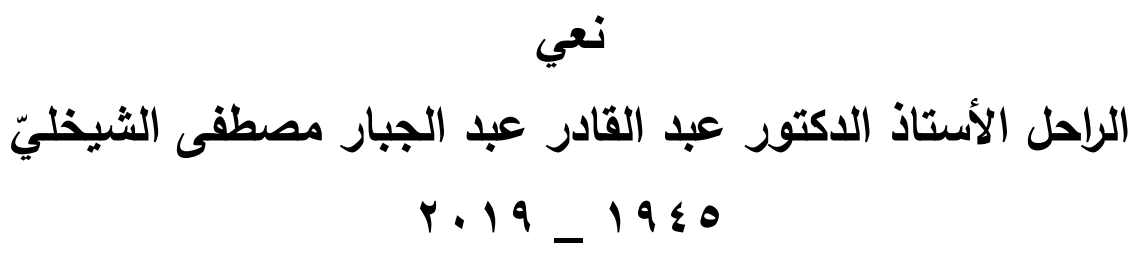

أ.د. - أد جابر خليل إبراهيم

كلية الآثار - جامعة الموصل

رئيس هيأة الآثار والتراث الأسبث

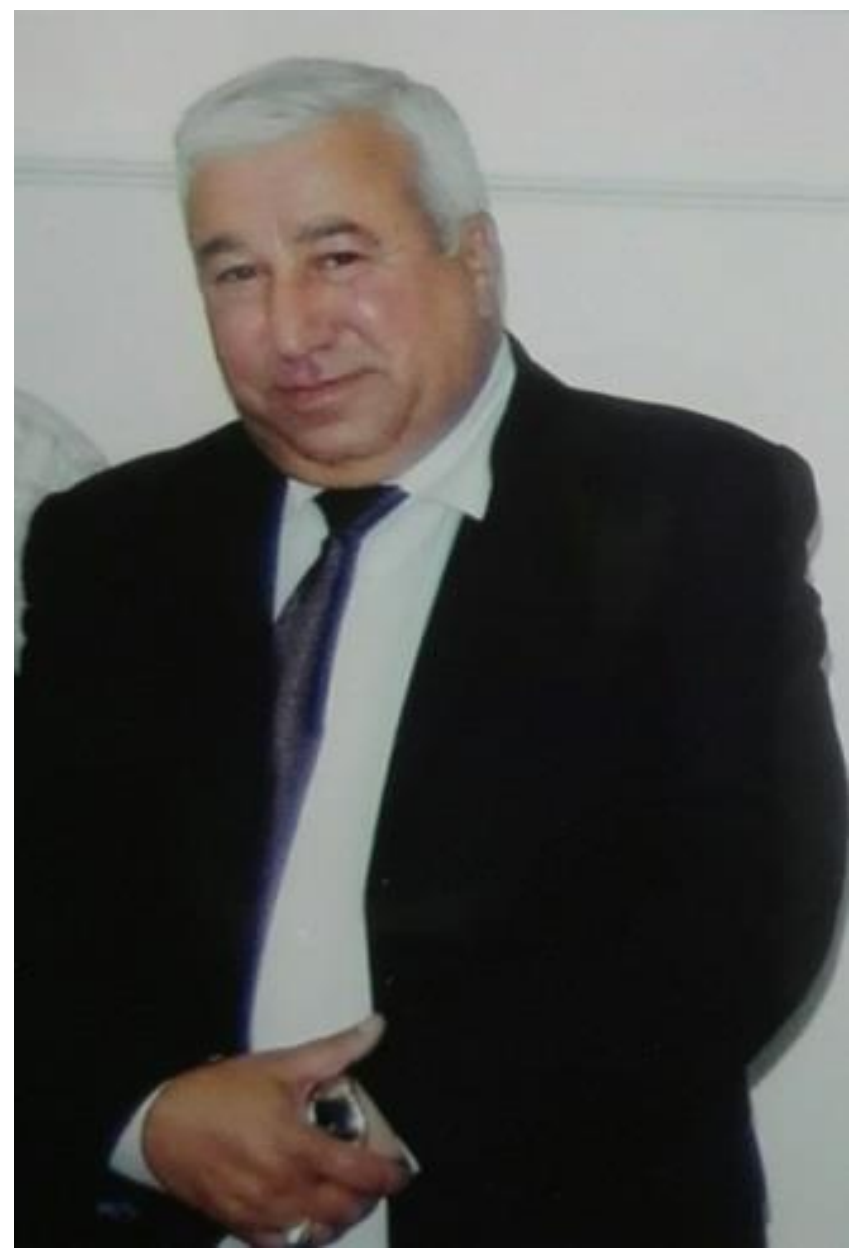

في يوم الجمعة الموافق •r أيلول 19 19 غادر الدكتور عبد القادر مطار بغداد الدولي منوجها الى مدينة اسطنبول بتركيا ، لإجراء فحوصات تتعلق بالقلب في إحدى مشافيها ، برافقه نجله أنس • بعد إجراء الفحوصات الطبية قرر الاطباء المختصين إجراء عملية جراحية كبرى في القلب .

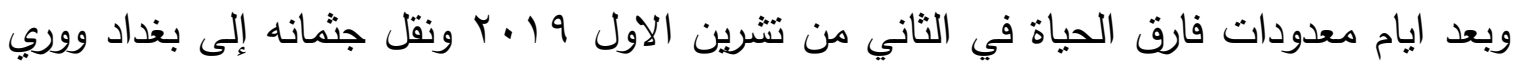

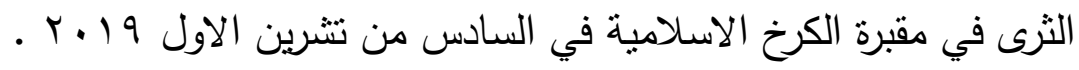


والفقد حالة مؤلمة ، والفراق هاجس مرعب ييقى كامناً في ذهن الإنسان وإن كان تفسيره هو انتقال من حياة زائلة إلى أخرى دائمة مستقرة .

ولد الفقيد عام 19 1 في حي عريق من أحياء مدينة بغداد معروف باسم (باب الثيخ ) نسبة إلى الثيخ الزاهد عبد القادر بن موسى بن عبداله الجيلي (الكيلاني) الذي فيه مرقده ومسجده دئه · الجامع أكمل المرحوم عبدالقادر دراسته الابتدائية والإعدادية في مدارس بغداد ثم التحق بعدها بقسم الآثار في كلية الآداب بجامعة بغداد وحصل على شهادة البكالوريوس في الاثار القديمة ـ وأهلته شهادته

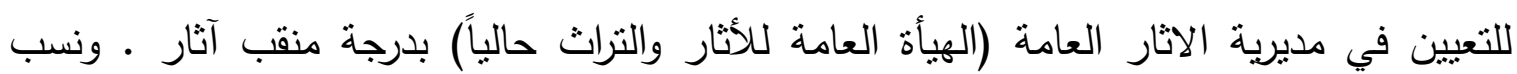
للعمل في دائرة التحريات وحماية المواقع الاثرية ـ والتحق يومئذٍ باللجان التي كانت تعد مؤلفين

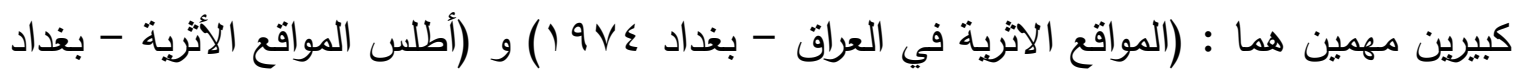

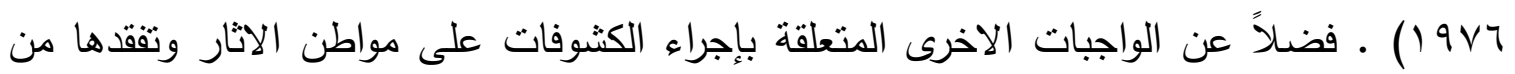
حين لآخر ، من أجل حمايتها من التجاوزات . في بداية شهر آذار من سنة 19 آشحت مديرية الاثار العامة يومها المرحوم عبد القادر

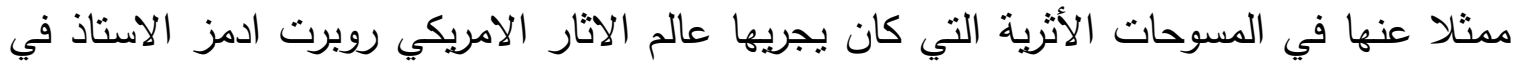

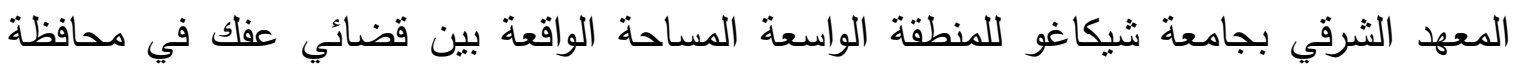

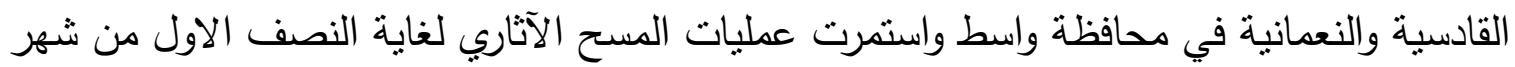
مارس من العام نفسه ـ والهدف من هذه المسوحات هو استكمال الدراسات الخاصة بمجاري الانهار والجداول الدارسة ، والتي كانت تروي المدن والقرى والحقول والبساتين في العصور القديمة ، والتي

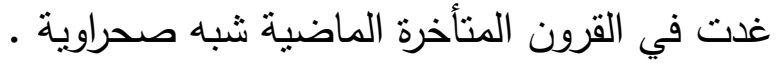
ومن الجدير بالذكر أن الاستاذ ادمز بدأ مشروعه هذا على مراحل ـ كانت الاولى في عام

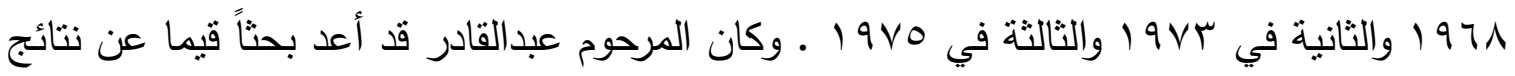

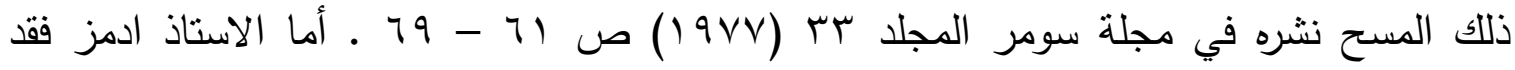
أصدر مؤلفه الثهير (Heartland Cities , Chicago 1981) كانت الأعمال الاثارية هذه علاوة على أعمال المسوحات في منطقة السهل الرسوبي ، قد أكسبت الفقيد مهارة في التحري والتتقيب التي

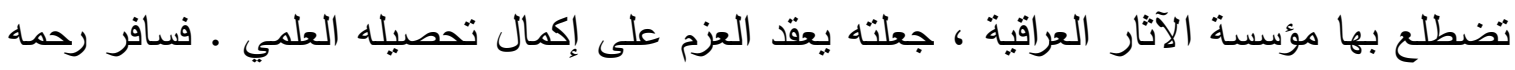

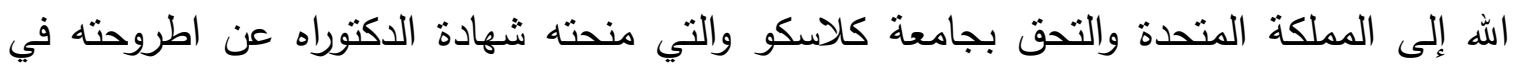


النصوص المسمارية المكتشفة في تليين مشهورين بحوض سهل حمرين هما (السيب وحداد) الواقعين

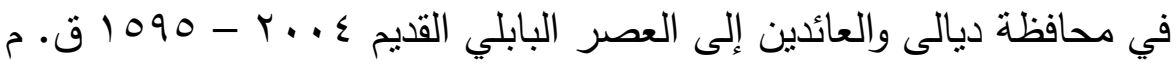

\section{The Old Babylonian Tablets From ME - TURAN (Tell AL SIB and Tell} HADAD) Univiersity of Glasgow June 1983

عاد الدكتور عبدالقادر إلى العراق والتحق بمؤسسة الآثار التي منحته اجازة دراسية لإكمال

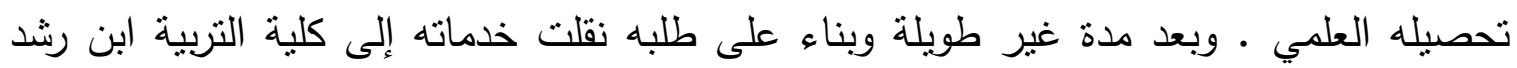
بجامعة بغداد لتدريس تاريخ العراق والوطن العربي في العصور القديمة إلا انه لم ينقطع عن دائرة الآثار والمتحف العراقي وفي الوقت نفسه كانت صلاته العلمية مع قسم الآثار بكلية الآداب في

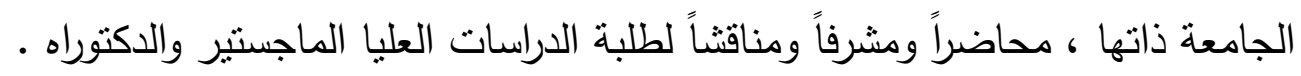
لم يقتصر نشاطه العلمي على كليته بل كان يلبي دعوات الجامعات العراقية لمناقتشة أطاريح

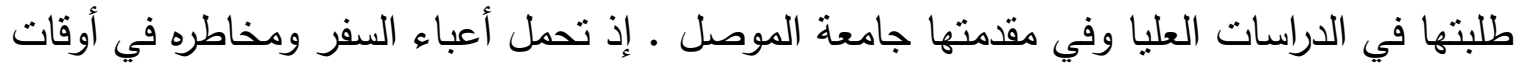

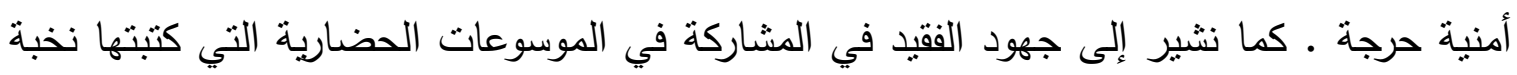

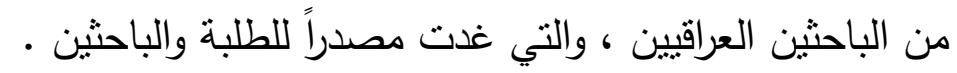

وفضلاً عن ذللك فقد تخرج على يدي الفقيد العديد من الآثاريين والمؤرخين في العراق فأصبح

بعض تلاميذه يقودون العملية التربوية في المدارس والجامعات العراقية .

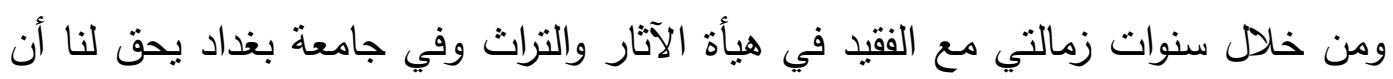

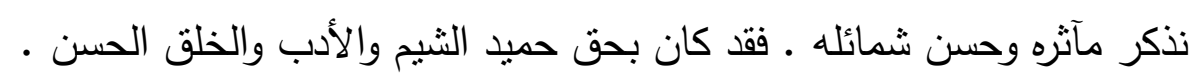

غادرنا المرحوم الدكتور عبدالقادر إلى عالم الآخرة وترك عند عند عائلئنه وزملائه وأصدقائه ومعارفه ومحبيه لوعة الحزن وألم الفراق ـ ندعو الله تعالى أن يتغده بواسع رحمته ، وأن يسكنه

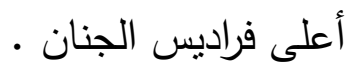

وإنا لله وإنا إليه راجعون 



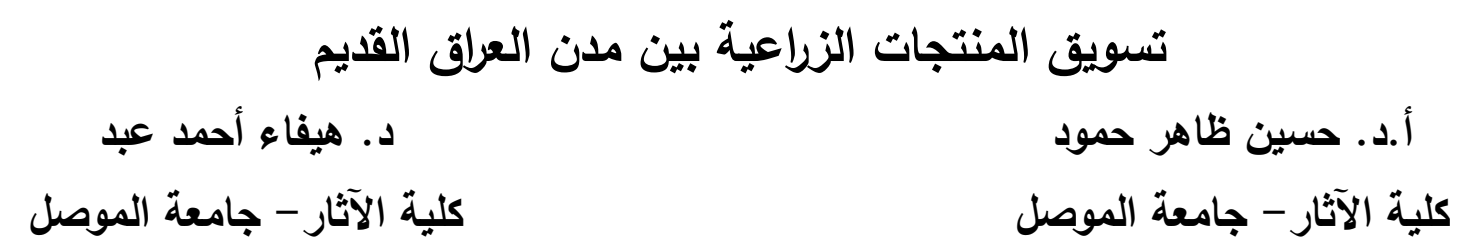

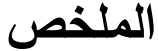

ان دراسة موضوع تسويق المنتجات الزراعية يعد مؤشراً لتقويم جانب مهم من اقتصاد

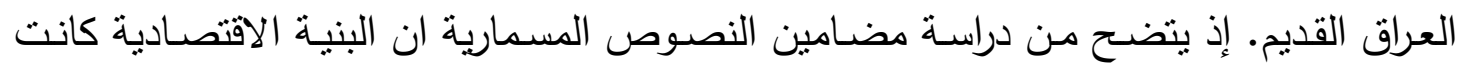

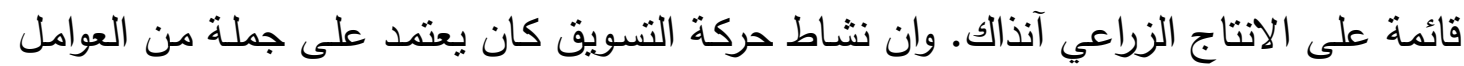

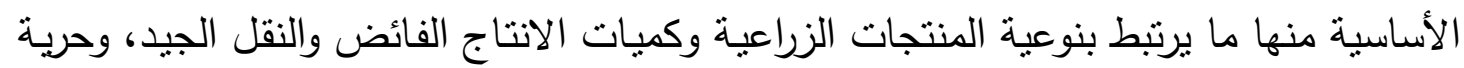
التبادل التجاري، إلى جانب تتظيم تعريفات الاسعار وثباتها بعامـة. كما كان للظروف البيئية

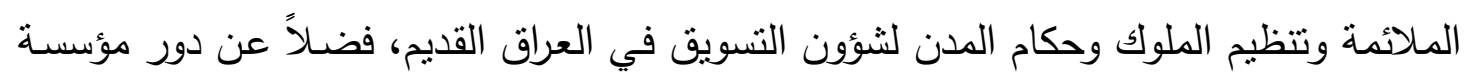
المعبد في عمليات التبادل التجاري.

\title{
The Agricultural Products Marketing in Ancient Iraqi Cities
}

\begin{abstract}
Tackling the topic of agricultural products marketing at the ancient ages refers to the evaluation of economy in Iraq at that time. Throughout the study of cuneiform texts, it is clear that structure of Iraqi economy was based on the agricultural production. The marketing activity depends on a group of essential factors, like the ones that are related to the type of agricultural products, the quantities of surplus products, the perfect transporting, and freedom exchanging and fixed tariffs for prices, the adequate environmental conditions and the marketing organized by kings and rulers of the Iraqi cities at that time and basically related to the foundation of temple which was responsible for all transactions and the processes of trading exchange.
\end{abstract}


المقدمة:

يعد موضوع التسويق من الاهمية بمكان في نمو اقتصاد البلدان وتطوره قديماً وحديثاً

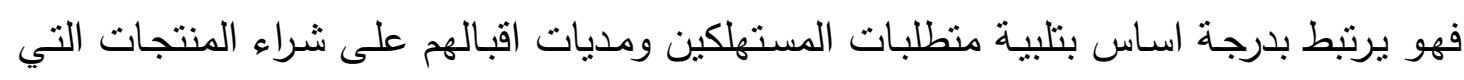

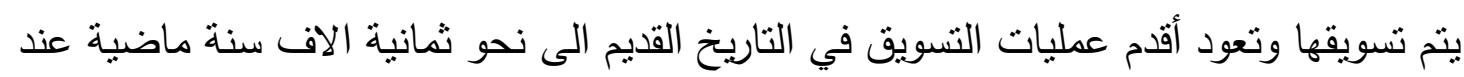

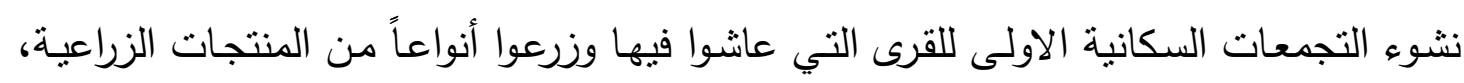

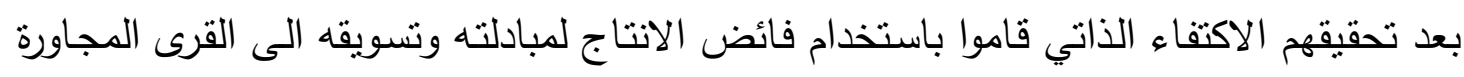

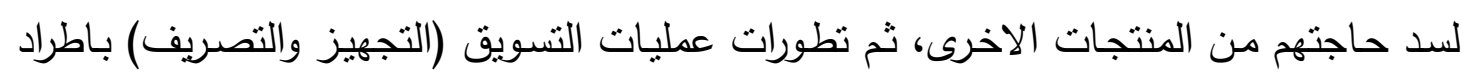

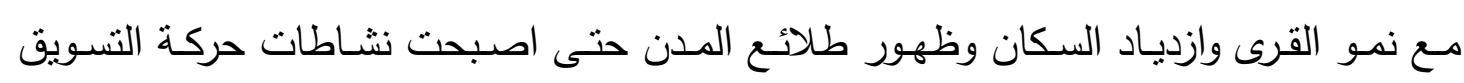
منظمة ويتم الاشراف عليها لتحقيق الفائدة لجميع العاملين في شؤونها بين مدن العراق القدئ لقديم.

\section{تسويق المنتجات الزراعية بين مدن العراق القديم}

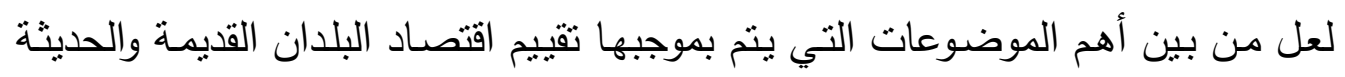

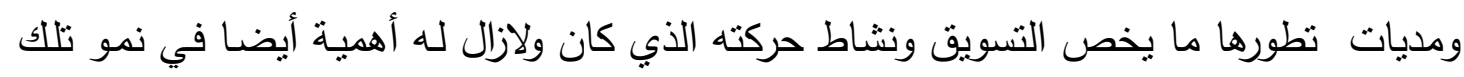

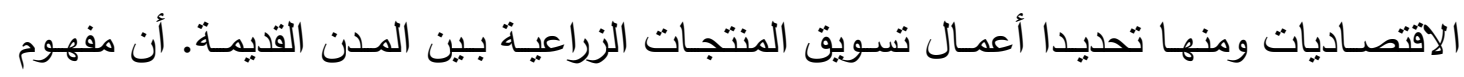

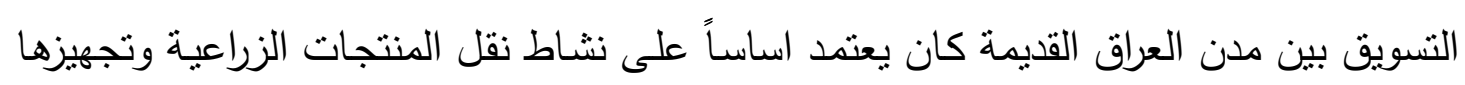

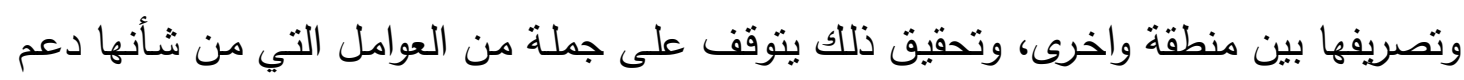

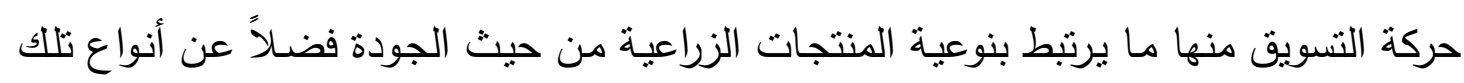

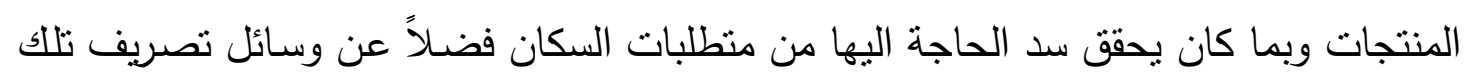

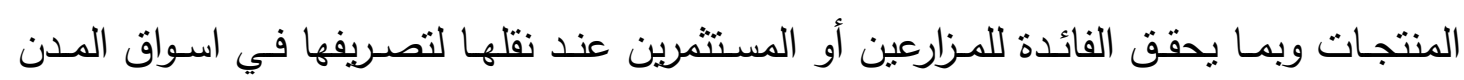
القديمة.

دون شك فإن نسب الأرباح المتحققة للمزارعين والمتاجرين بالمنتجات الزراعية ونشاط

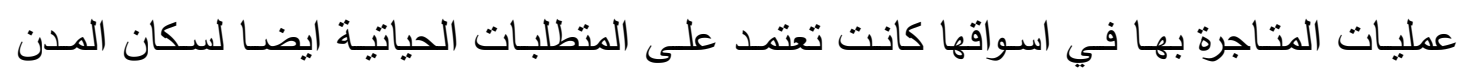

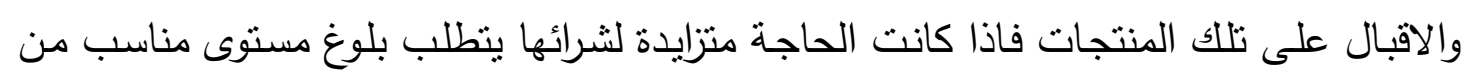

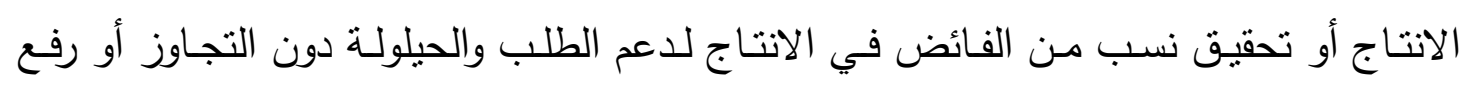

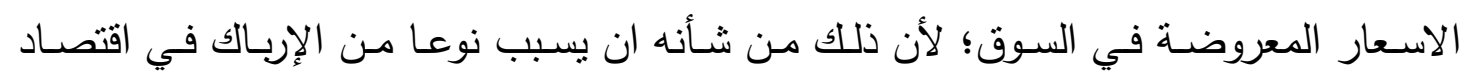
السوق.

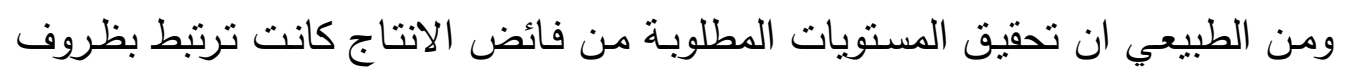

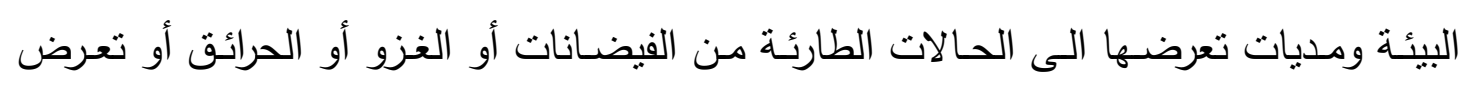

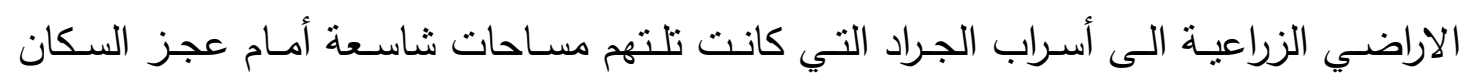

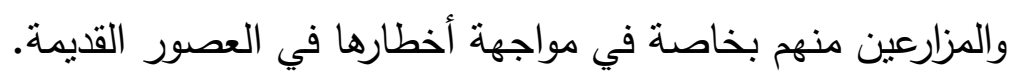




\section{أ.د. حسين ظاهر حمود}

تسويق المنتجات الزراعية بين مدن العرلق القديم

\section{د. هيفاء أحمد عبد}

الى ذلك من الضروري الإشـارة الى مديات توافر المياه فيما يخص الاراضـي المعتمدة على الأمطار في الأقسام الثمالية من العراق أو التي كانت تعتمد على السقي عبر مشاريع الري

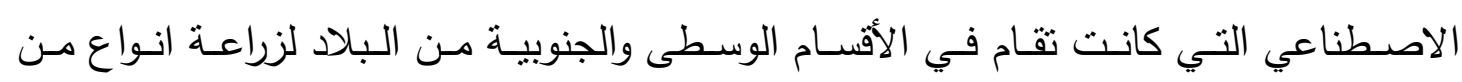

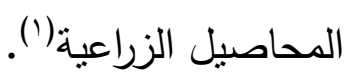

كذلك يمكن اضـافة عامل النقل الذي كان ولازال له أثره الواضـح في بلوغ أسواق المدن

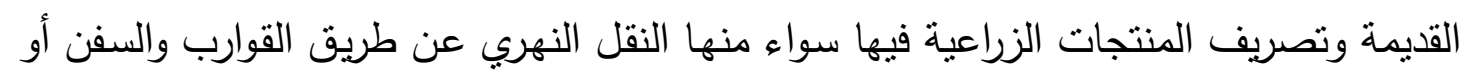

بوساطة قوافل الحمير في نقل حمولات المنتجات وتنويقها الى جهاتها المقصودة(؟). ونتير الدلائل الاثرية المتيسرة الى زراعة أصناف من الحبوب في العراق ومنذ عصور مبكرة من تأريخه وتحسين نوعية المنتجات لأغراض التسويث في التجمعات الزراعية الأولى بعد رلئ ظهور الحياة المستقرة في القرى وازدياد السكان فيها قبل أكثر من عشرة الاف سنة مضت لَّات. فيما اصطلح على تسميته بالعصر الحجري الحديث وما تبع بعده من تحولات اقتصسادية واجتماعية مهمة في تطور مسيرة المجتمع البشري القديم. وقد ربط المتخصصون في دراسة الاثار والحضارات القديمة ذلك التحول بممارسة الاقتصاد الانتاجي الذي اعتمد أساسا على زراعة أنواع من منتجات الحبوب وتسويقها بين المجاميع في

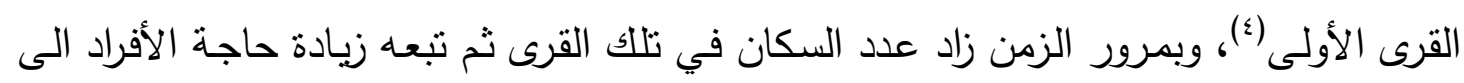

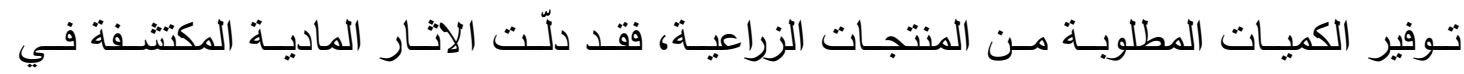
المستوطنات الزراعيـة القديمـة التي تعود الى حدود الالف التاسـع - الثامن ق.م عن ممارسـة السكان نقل وتسويق أنواع من منتجاتهم الزراعية الفائضة فيما بينها، وكان ذلك يتم بالتبادل او ما يسمى بالمقايضة عبر تبادل سلعة او منتوج بمنتوج آخر (•). فقد عثر المنقبون على أنواع من الحبوب التي تحتوب على نسبة عالية من البروتين مثل بذور الكتان والعدس والبازلاء في موقع ام الدباغية (قرب الحضر) والذي يعود تاريخه الى ما يقارب من . . . 7 سنة ق. م ومن المعروف ان هذه البذور لا يمكن ان تتمو في النطاق المذكور ؛ لأنه يقع في سهل جاف بينما تحتاج نمو تلك البذور الى عمليات إرواء مستمرة، كما ان طوبوغرافية الموقع لا تسمح باستخدام تقنية الري فيها وان امكانية سقي تلك البذور كان بعيداً في ذلك الوقت ايضا(ج)، مما يؤشر الى ان هذه البذور تم تسويقها من موقع زراعي آخر استخدم

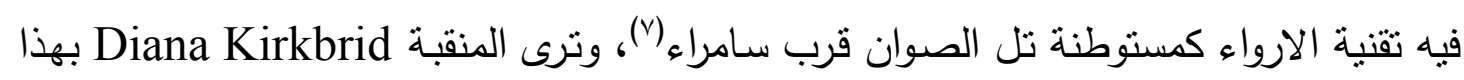
الخصوص ان سكان موقع ام الدباغية قد حصلوا على تلك الحبوب من خلال مبادلتها بالجلود، جلود الحيوانات التي اصطادوها في مناطقهم(^). كذللك فإن هناك من الادلة التي نؤشر الى 
تسويق المنتجات الزراعيـة بين مواقع تل الصسوان وجرمو وحسونة وشمشـارة بمنتجات الحبوب الفائضة والآلات والادوات الزراعية(9). ومسن العصـور اللاحقـة هنـاك مـن المؤشـرات على تسـويق المنتجـات بين مواقع العبيد

$$
\text { والوركاء في جنوب العراق وشماله(·'). }
$$

الى ذلك تزداد معرفتتا عن حركة التسويق وعملياتها المختلفة باطراد في العصور التاريخية

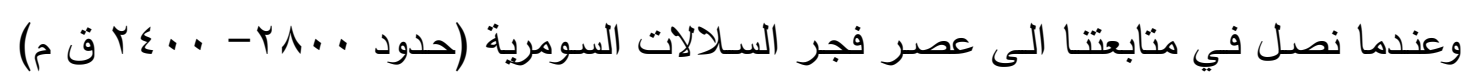
نــلمس مـن مضــامين بعـض النصـوص المسـمارية سـيطرة المعابـد علـى الثــؤون الزراعيـة

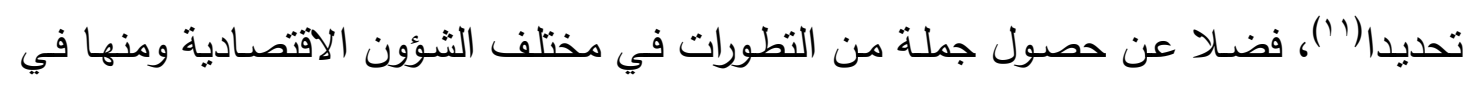
اتساع مساحات الاراضي الزراعية وتتوع المحاصيل فضلا عن تقدم الاساليب الزراعية وادواتها مما ساعد في زيادة الانتاج وتحقيق الفائض منها لأغراض التسويق كما تعكس تلك النصوص تفاصبل حركة المبادلات بين مدن العراق القديم، فقد كانت السـلالات الحاكمـة في كل مدينـة سومرية تترف على عمليات التسويق وتتظيمها (r'ا"). ولم يستمر هذا النمط الاقتصادي في العصور اللاحقة بل حدثت فيه بعض التطورات في

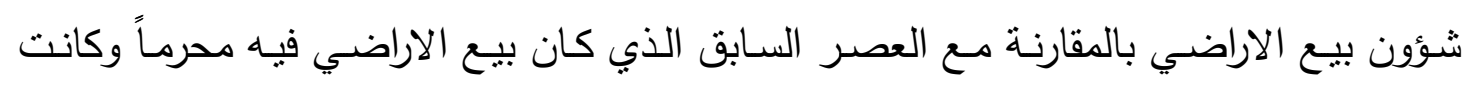

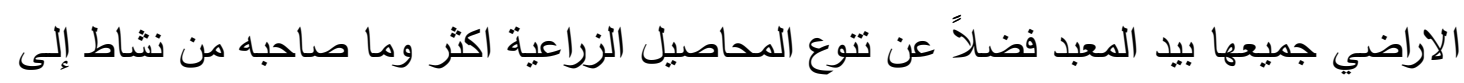
جانب مشاريع الري وكري الأنهار لسقي المزروعات فضـلا عن حرية مبادلة المنتجات من قبل المـزارعين وتسـويق منتجـاتهم الزراعيـة وبمـا يحقـق لهـم الاربــاح المرجـوة فـي إدارة شـؤونهم

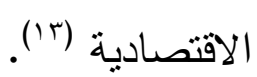

وبذلك اختفت كثير من القيود التي كانت تحد نشاط الافراد مثلمـا كان عليه الحال في

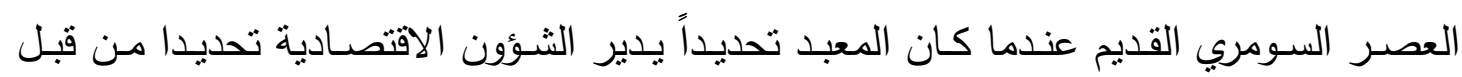
المعابد، الا ان هذا التوجه قد تغيّر فيما بعد بحلول العصر الاكدي ومن ثم العصور التالية وساد نوع من الحرية في إدارة الثؤون الاقتصادية من قبل الافراد والقصور فضـلا عن اعطاء الحرية للأفراد والمزارعين الذين كانت لهم اراضيهم الخاصة ولهم حق التصرف بها وزراعتها بأنواع من المنتجات الزراعية وتسويقها (ء).). هذا ويتضح تتظيم شؤون الحياة الاقتصادية في العصر البابلي القديم (ع . . ؟- 1090 ق. م) بوضـوح عـن طريـق دراسـة مضــامين النصـوص المسـمارية، اذ كـان لـذلك التنظيم انعكاسـاته الايجابية على نشاط حركة التسويق كذلك كان للقوانين الصادرة تأثيرها الواضح في تتظيم شؤون التجارة والتجـار وتتبيت تعريفات اسـعار المنتجـات الزراعيـة الاساسية في الحيـاة اليوميـة وكما يتضح ذلك من قانون اشنونا(10). 


\section{أ.د. حسين ظاهر حمود}

تسويق المنتجات الزراعية بين مدن العرلق القديم

\section{د. هيفاء أحمد عبد}

كما يفهم من مضامين مواد قانون حمورابي تتظيم شؤون الزراعة والمحافظة على تطويرها ودعم الانتاج الزراعي وفسح المجال أمام مبادرات الأفراد لتتظيم الانتاج الزراعي وتكثيفه وتوسيع

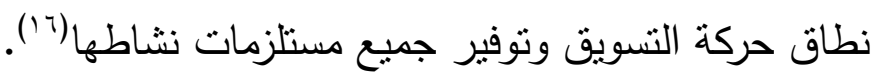

لقد كان تسويق المنتجات الزراعية يساهم في كل مدينـة من مدن العراق القديم برخائها وتحقيق نوع من التكامل الاقتصادي فيها نتيجة سد الحاجة المحلية في كل مدينة من تلك المدن،

ومن ثم تحقيق الفوائد المالية للعاملين فيها جميعا(IV). الـى ذلك كـان مـن أهـم عوامـل نشـاط حركـة التسـويق بـين مـدن العـراق القديم تتـوع المنتجات الزراعية، فقد تميزت كل مدينة أو منطقة بإنتاج او تسويق نوع معين من المحاصيل اليها و من ثم ساهم في اقبال سكان كل مدينة على شرائها؛ لأنها كانت ذات اهية كبيرة في حياتهم اليومية ويمكن القول إنه كان لتتوع خصائص بيئة العراق الطبيعيـة صلة مباشرة بتتوع انتاج المحاصيل الزراعيـة، فكمـا هو معروف ان بيئة العراق تتألف من اربعـة منـاطق طبيعيـة رئيسـة هي: منطقة السـل الرسوبي والمنطقة المتموجـة والمنطقة الجبلية والمنطقة الصحراوية، وبذلك فإن مظاهر البيئة الطبيعية تتباين في ارض العراق تباينا كبيرا من حيث التضـاريس كما تتباين من حيث ظروف المناخ السائدة في كل منها من حيث تفاوت درجات الحرارة والبرودة وكميات الامطار التي تهطل عليها وتغييرها الفصلي اثتاء العام(^'). ومن دون شك كان لهذا التباين أثزه الواضح في حياة السكان وتتوع نشاطاتهم الزراعية اذ نتج عنه نوع من التفاوت في كمية ونوعية المنتجات الزراعية مما كان له أثزه الفاعل في تهيئة الظروف الملائمة لقيام السكان بتصريف منتجاتهم الزراعية ومن ثم نشاط حركة التسويق بين المدن في العراق القديم. وممـا تجدر الاشـارة اليـه انـه ورد في بعض النصـوص المسمارية بعض المعلومـات ذات

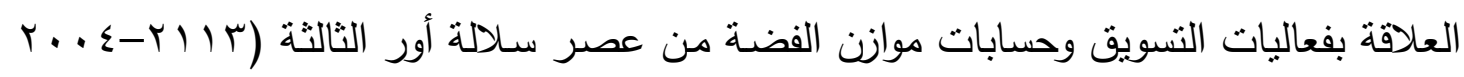
ق. م) وقد كثفت هذه النصوص في مدينة أوما، وتعد على قدر من الاهمية في دراسـة شؤون التسويق وتقسم هذه المجموعة من النصوص الى ثناثة أقسام:

• نصوص تسمى برأس المال (assist) وتعرف باللغة السومرية Sag.níg.ga.ra.kam/ak • نصوص النفقات (Expenditure) واشثير لها بالسومرية zi.ga.am أو بالمصطلح

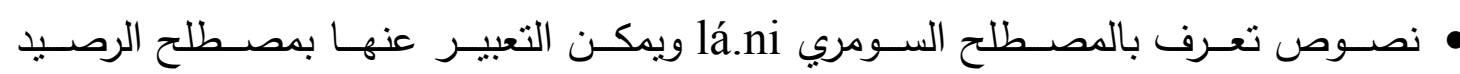
المنبقي (19) ان هذه النصوص تعدّ على درجة من الاهمية في دراسة حسابات الموازنة في مدينة اوما وحركـة التسـويق فيهـا، اذ يمكن ان بسـتـل مـن تلك النصـوص على طبيعـة المبـادلات بـين المستثربن والتجار ووصـول البضـائع الى الاسواق بشكل مباشر من المنتجين أو عن طربق 
الوسطاء في الغالب إذ كانوا المسؤولين عن الصرف والخزن، كما يفهم من مضامين بعض تلكا

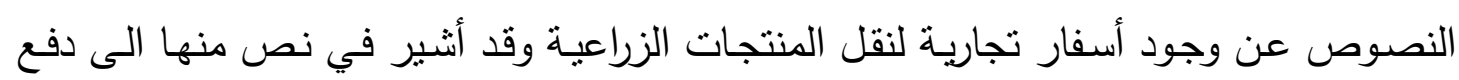

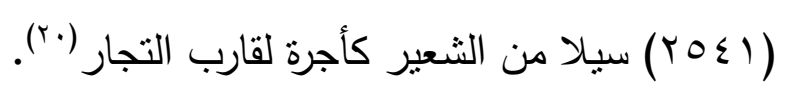

يمكن تقسيم اهم المنتجات الزراعية التي كانت عرضة للتسويق بين مدن العراق القديم في الآتي:

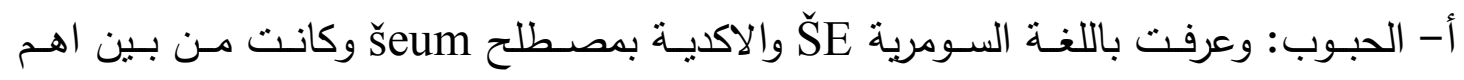

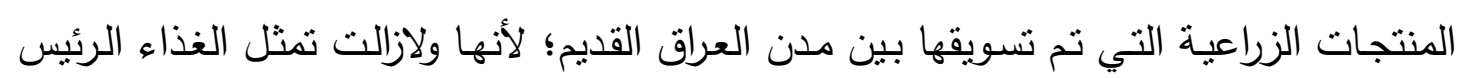

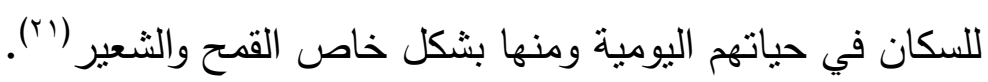
وقد اشتهرت ارض العراق في عصوره كافة بزراعة هذين المنتوجين نتيجة لخصوبة ونية تربته

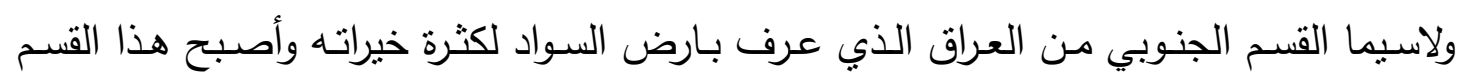

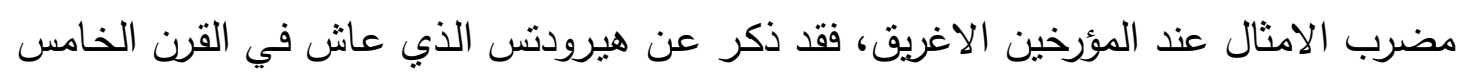

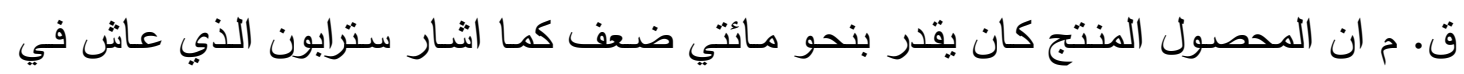

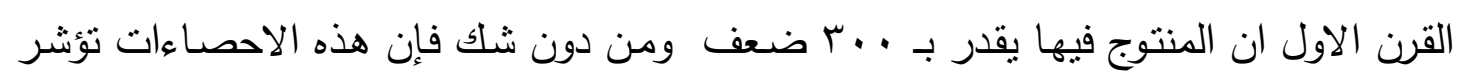

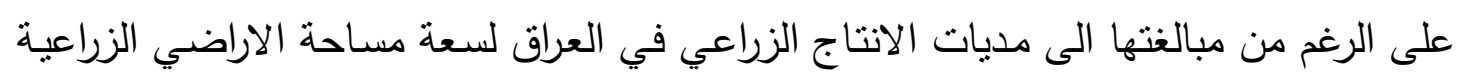

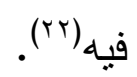

لقد كانت حركة النسويق نشيطه بين مدن العراق القديم(rr)، في مبادلة منتوج الثعير

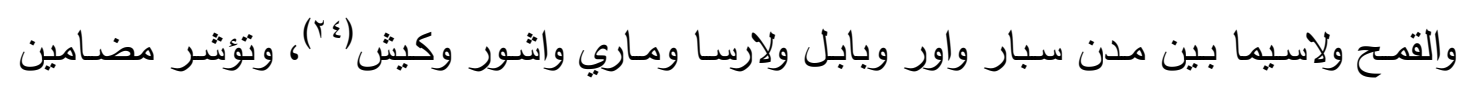

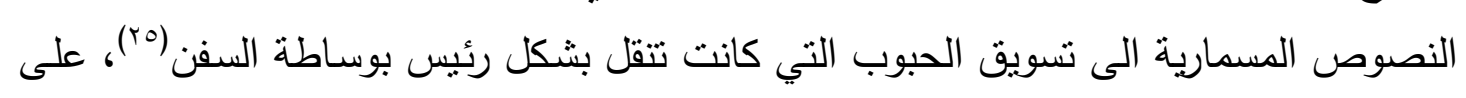

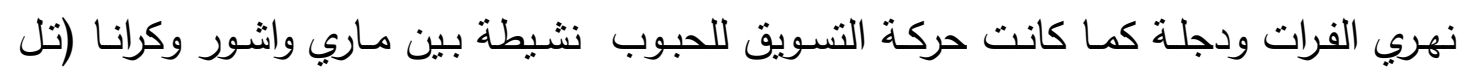
الرماح) بوساطة القواقل البرية(ז؟). وقد ذكر في العديد من النصوص المسمارية عقود شراء كميات الحبوب ومنها الثعير

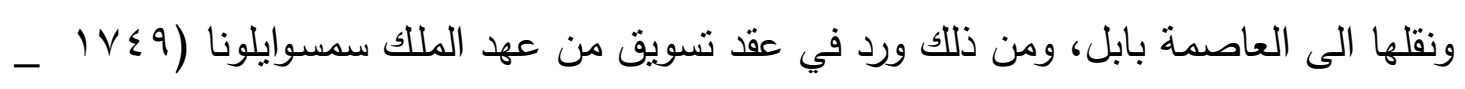

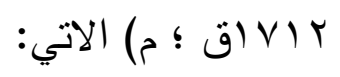

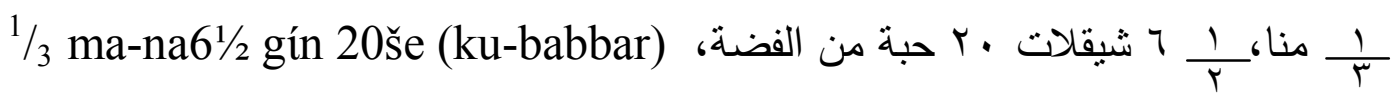

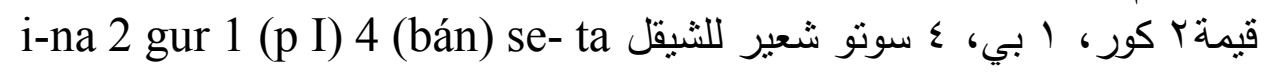

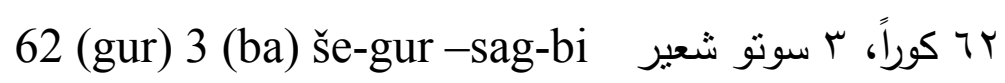

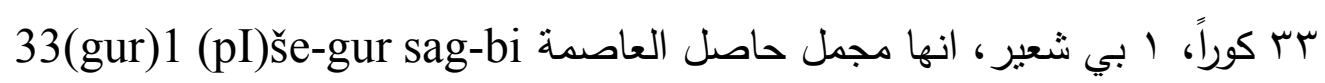

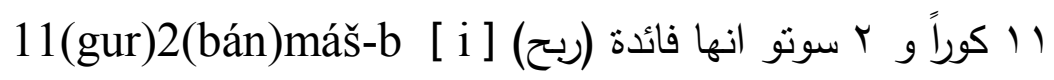

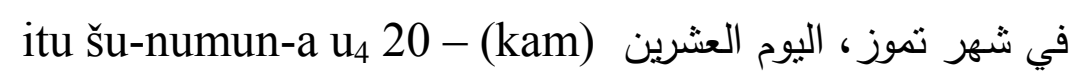




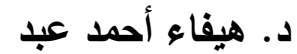

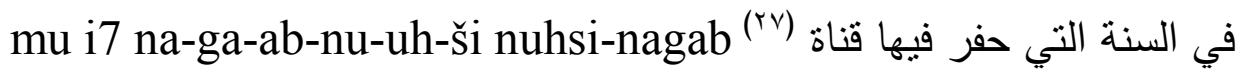
كما ورد في عقد آخر يخص استلام حبوب (الثعير) شحنت بالسفن الى بابل الاتي: 300 še -gur na-ah-lum كور شعير نم غربلتها (تنظيفها) ب r. .

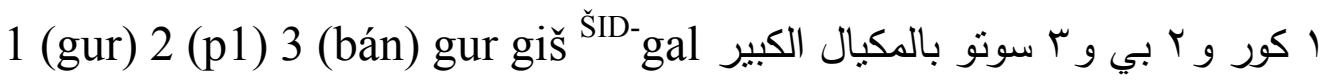

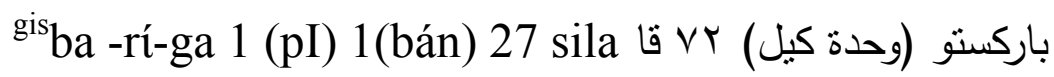
وفق المكيال الأساس وكاس

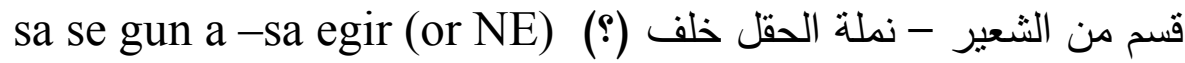
Ša pa -hu -ú pa -huu D1 (or kI) UDTU.UD.KA.DINGIR.RA يستحق الدفع ؟)... الى بابل

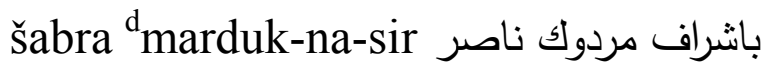
ma-ni-dub kar kA-DINGIR.RA ${ }^{\text {ki(rA) }}$

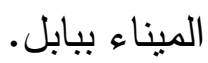

الى ذلك يفهم من مضمون رسالة ارسلها شخص يدعى ياسم سمو yasim -samu الى لئل

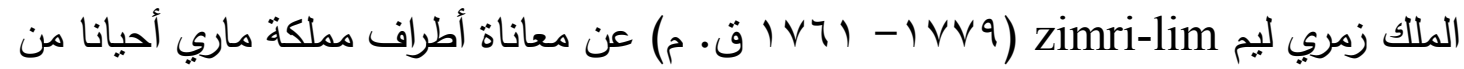
قلة الحبوب لذا تم تبليغه فيها عن تسويق كمية كبيرة من الثُعير كانت في طريقها الى ماري وان

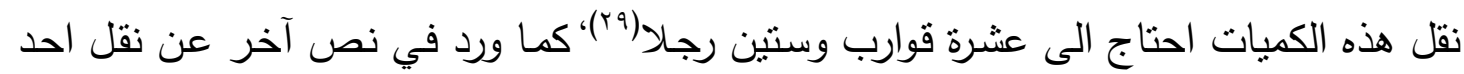

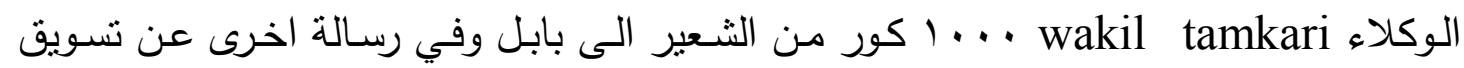

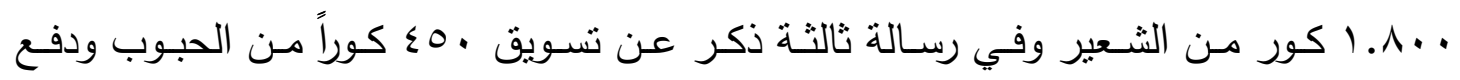

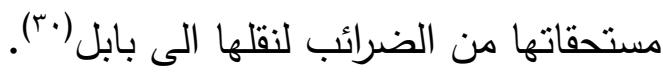
اما القمح فقد كان له اهمية قصوى في حياة السكان، وكانت زراعته بالمقارنة مع الثعير قليلة

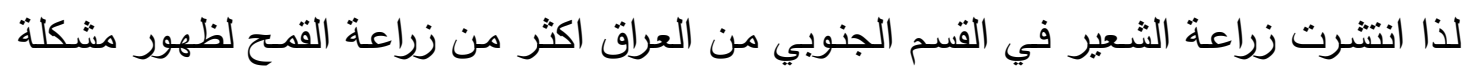

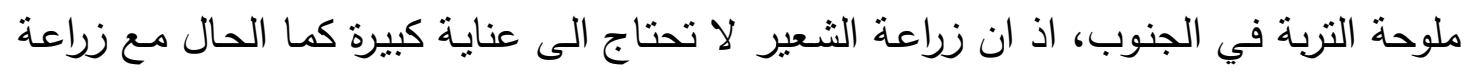
القمح، كذلك فإن تعرض البلاد في بعض الاحيان الى ظروف مناخية قاسية من ارتفاع درجات

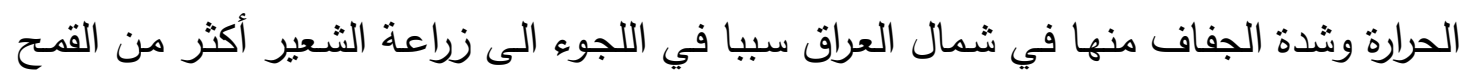
لذا تتكرر الاثـارة في النصوص الى الثعبير اكثر من القهـح في حركة التسويق من تجهيز

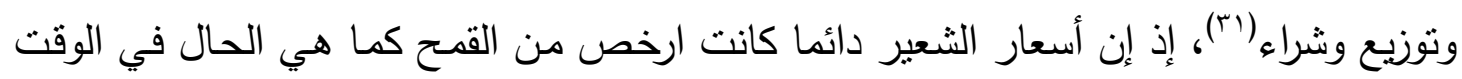

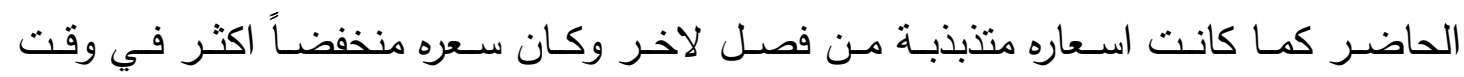

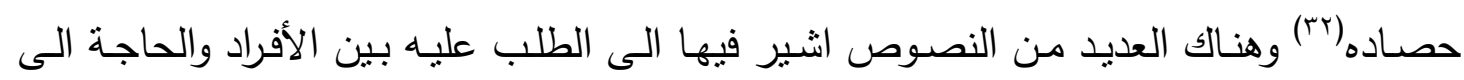

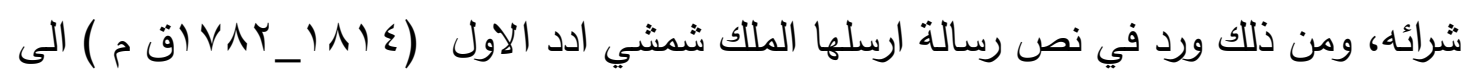

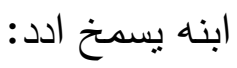


" ان يذهب على الدوام للإثراف على تتظيم عمليات نقل القمح " (Tr) كذلك ذكر في نص رسالة أخرى مرسلة من شخص يدعى اويل - شمش الى أبيه عن شراء الكميات المطلوبة من ندات

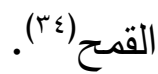

لقد كانت شؤون التجارة مزدهرة في بلاد بابل وكانت السفن نأني اليها من مختلف الارجاء

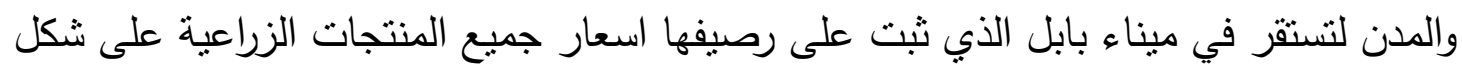

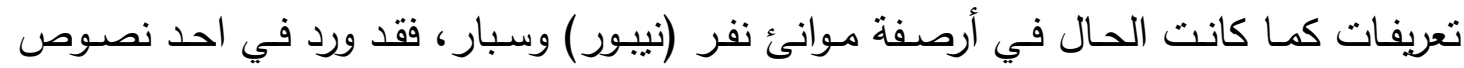
الرسائل عن نقل مواد متتوعة الى بابل بوساطة السفن من المدن الثمالية ومنها ورد عن ارسال

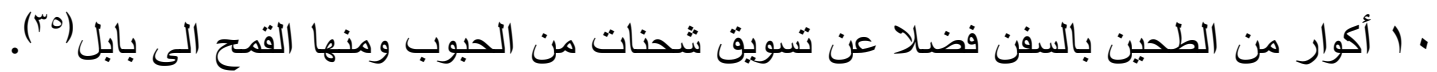
ولعل من بين اهم الرسائل التي يمكن الاشارة بهذا الصدد عن حاجة ددينة اور الماسـة

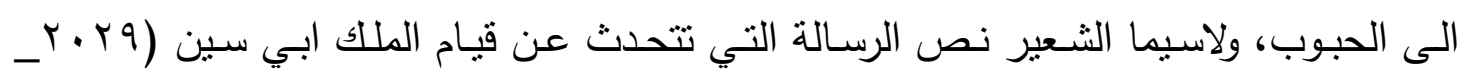

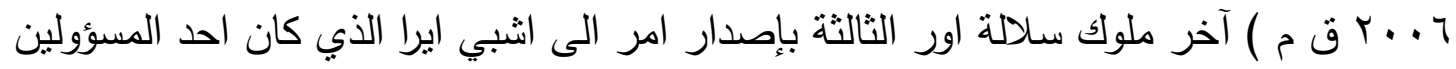

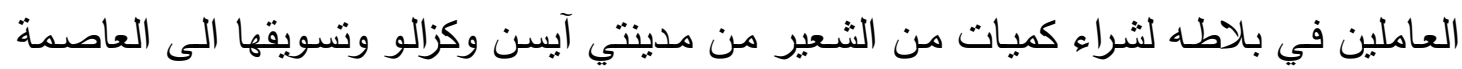

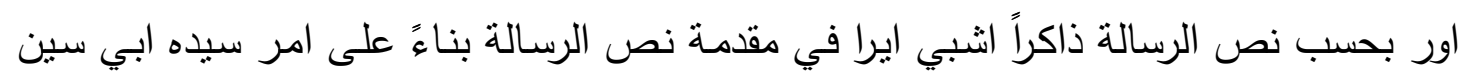

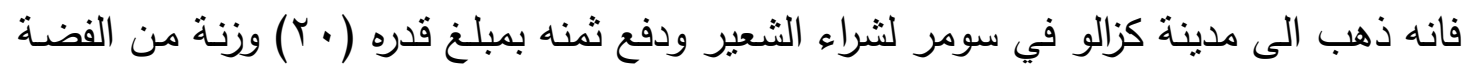

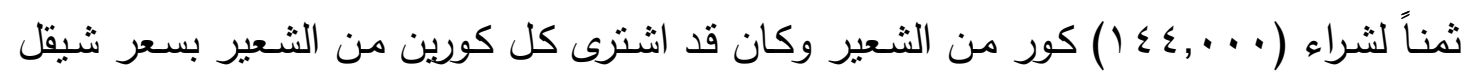
واحد من الفضة أب كل كور واحد بنصف شيقل..... وقد طلب اشبي ايرا من الملك ابي سين

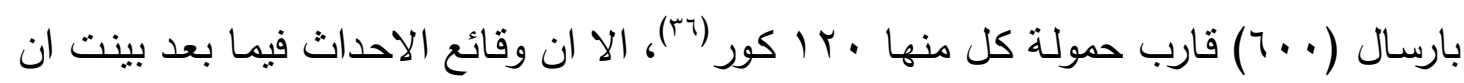
كميات الحبوب لم تصل الى مدينة اور وكان يعاني سكانها من مجاعة شديدة تسببت في النهاية بسقوطها. ومما يرتبط بموضوع الحبوب فقد عرف العراقيون القدماء زراعة الذرة كما عرفوا زراعة

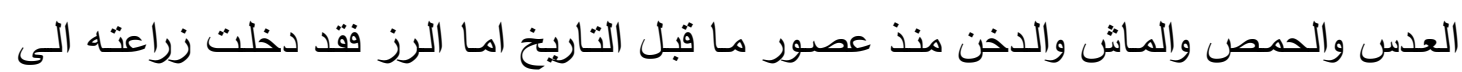

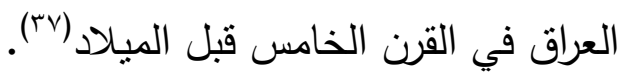
ب- التمور : لقد شكل النخيل ومنتجاتها مـادة غذائية رئيسة للعراقيين قديما. كما كانت مادة

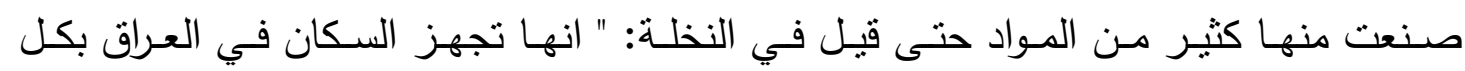

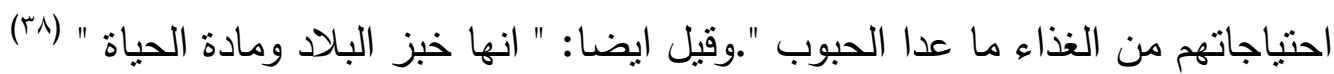

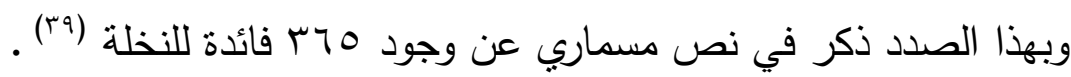

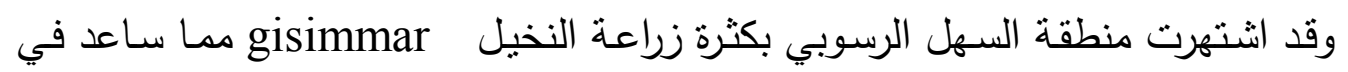

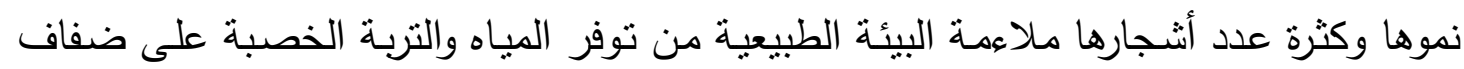

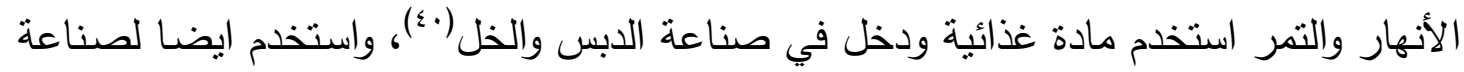

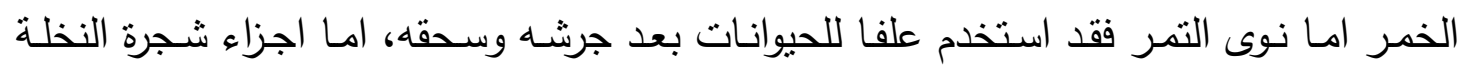




\section{أ.د. حسين ظاهر حمود \\ د. هيفاء أحمد عبد}

تسويق المنتجات الزراعية بين مدن العرلق القديم

الاخرى مثل سعفها وليفها وجذوعها فقد استخدمت في صناعة الحبال وصناعة الاثاث والحصران

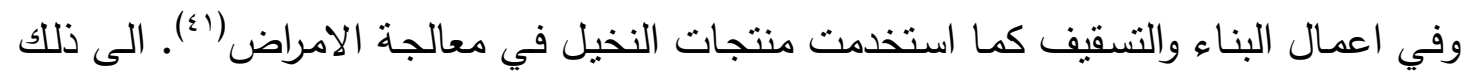
احتفظ هذا المنتوج بأهميته بين المنتجات الزراعية الاخرى اذ يمتاز محصول التمر بامكانية

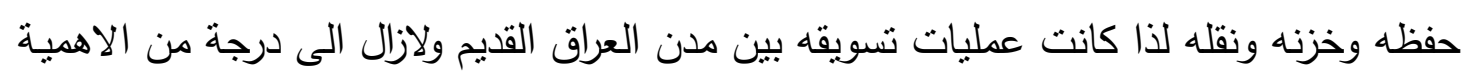
وتحقق المتاجرة بها ارباحا جيدة (r).

لقد كانت النخيل من أهم أثجار البساتين وقد كثر زراعتها في الجنوب وكانت محور

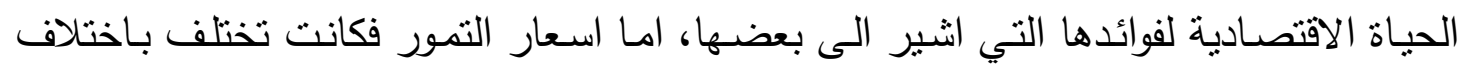

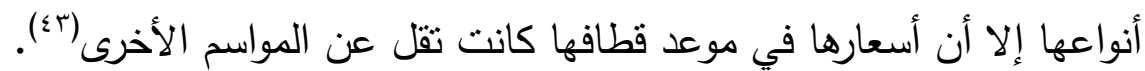
لقد ورد في العديد من النصوص اشـارت الى تسويق كميات التمور ، ومن ذلك ورد في

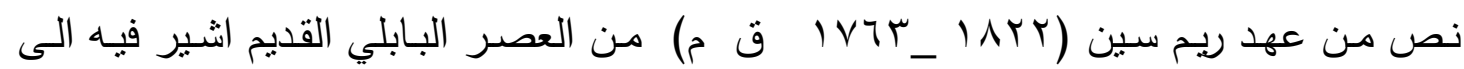
كميات التمور لمنتجة من احد البساتين:

(1) 7 (gur) 1 (b) gur ú - hi -in zú- lum-bi ) V- كور 1 بي تمور نصف ناضجة التي (كمية ال) تمور جافة

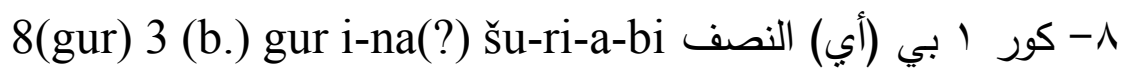

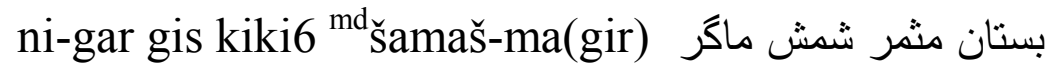
ki dsamas-ma-gir من شمش ماكر

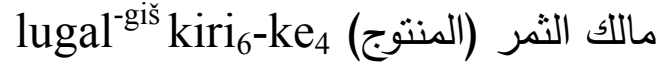
mpi-ir-hu-um بيرخوم

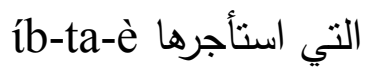
itu ${ }^{\text {gišapin }-d u 8-a ~ w a r a h ~ s a m u a ~ ف ي ~ ا ل ث ا ن ي ~ م ن ~ ش ه ر ~}$

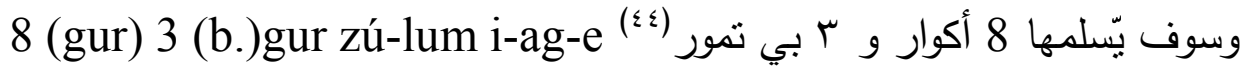
كذللك ورد في العديد من النصوص عن تسويق كميات من التمور على ارصفة المدن القديمة

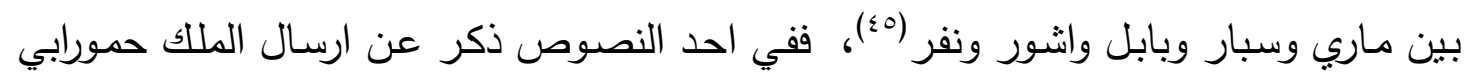
بحدود .. جr كور من التمور من بابل اذ قام موظفوا الملك بالاثشراف على شحن هذه الكمية

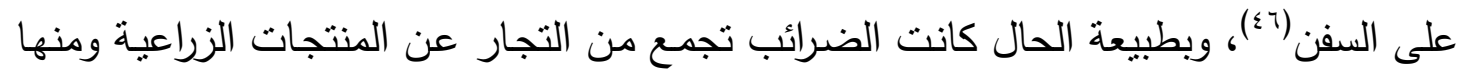
التمور التي كان يتم تسويقها في جميع مدن العراق القديم و في مدينة بابل تحديدا وكان يشرف

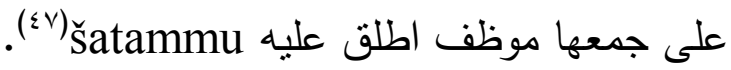

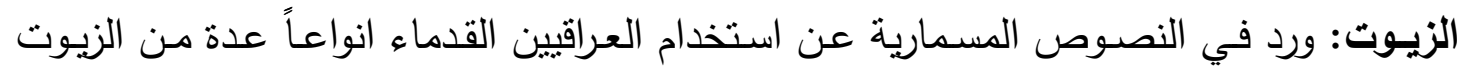
النباتية لحاجة السكان المتزايدة لها في مطابخ القصور والمعابد والبيوت العامة لاعداد الاطعمة العنة 
كما استخدمت لتزييت ومسح المواشير للاسطوانات الفخارية وللانارة ايضـا(^乞)، كذلك استخدمت الزيوت النباتية بانواعها وحسب ما ورد في مضامين النصوص لمعا لجة العديد من الامراض(9 ؛) وقد اطلق على كلمة الزيت في السومرية Igis وفي اللغة الاكدية تسمية samnu ونظرا لاهمية الزيوت فقد عمل المشرع العراقي القديم على تثبيت اسعاره في السوق والحيلولة دون رفعه في مملكة اشنونا، ويتضح ذلك في قانون اشنونا إذ نقرأ:

"ا كور من الحبوب بشيقل واحد من الفضة ب قا زبت نقي بشيقل واحد من الفضة ا سوتو و r قا من زيت السمسم بشيقل واحد من الفضة ا سوتو و 0 قا من شحم الخنزير بشيقل واحد من الفضة

وفي عهد الملك سين كاشد ملك الوركاء أصدر بدوره تعريفة بأسعار المواد الزراعيـة المهمـة ورد فيها:

$$
\begin{aligned}
& \text { r كور من الحبوب بشيقل واحد من الفضة } \\
& \text { ب قا من الزيت بشيقل واحد من الفضة } \\
& \text { r اصناف الصوف بشيقل واحد من الفضة }
\end{aligned}
$$

كما اصدر الملك شمشـي أدد الأول قائمسة بالأسعار ورد في نصوصسه ان الأسعار في بـلاد

$$
\text { اشور كانت كالاتي: }
$$

$$
\begin{aligned}
& \text { r كور من الحبوب بشيقل واحد من الفضة (0) } \\
& \text { ب قا من الزيت بثيقل واحد من الفضة }
\end{aligned}
$$

ومن أنواع الزبوت التي ذكرت في النصوص زبت السمسم والسمسم من المحاصيل الزراعية

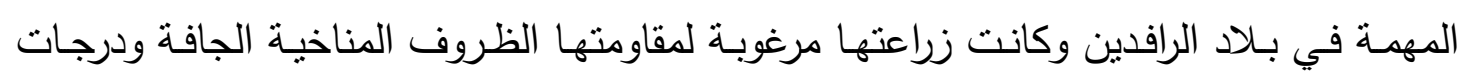
الحرارة العالية(1). (1).

وعرف معنى السمسم في السومرية بـ حب شجرة الزيت وكان سعره غاليا وقليل الزراعة في شمال العراق ثم تحسنت زراعته في العصر الاشوري الحديث (1) (1) (ا7 ق م) وكانت قيمته

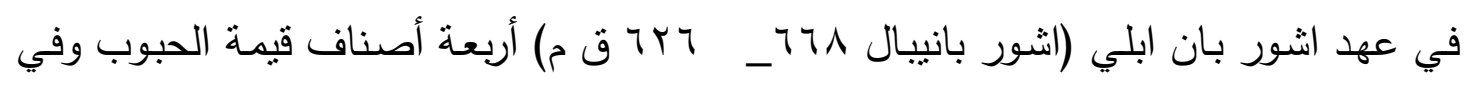

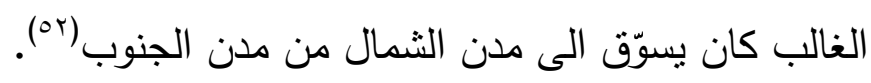
كذلك عرف الاشوريون خصائص الزيتون من البلدان المجاورة وجلبوه وزرعوه في بـاد اشور لاستخراج الزيت منهه، كما وردت في النصوص اسماء نباتات أخرى تستخرج منها الزيوت مثل زيت الكتان واللفت وحب العزير (ro)، ومن انواع الزيوت الاخرى زيت القصب والزيت النقي وزيت

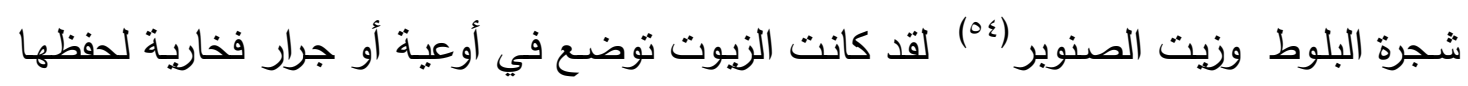
وخزنها ومن ثم تتقل الى جهات التسويق(00). 


\section{د. هيفاء أحمد عبد}

لقد اثـير الى الزيـوت والبـذر التي كانـت تسـتخرج منهـا في العديد مـن النصسوص إلا أن مضامين تلأك النصوص مقتضبة بشكل عام، ومن ذلك ما ورد في نص الرسالة الآتية: " ليبعث أخوتي عفصـاً بما قيمته منا من الفضـة وليأت رسولكم الي سأرسل سمسماً أبيض مقبولا لدى

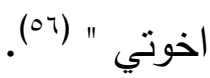
وفي نص اخر ورد عن ارسال: " لتز واحد من الزبت من الدرجة الاولى للمشعل الموجود أمام الالههة (ov)

الفواكه والخضروات: من المنتجات الزراعية المهمة التي تمت زراعتها وتسويقها بين مدن العراق القديم منذ العصور السومرية القديمة اشجار العنب في ضـلال النخيل ولم تدخل زراعة العنب الى مدن شمال العراق الا في الاف الاول ق. م، اذ انتسرت زراعته فيما بعد الى درجة في بـلاد اشور (^^)، مما يؤشر الى ان منتوج العنب كان يسوق الى مدن الثمال في العصور السومرية القديمة تبعاً لاحصائية اجراها الباحثون للنصوص المكتشفة في موقع حران (اورفه جنوب نركيا) مـن العصـر الاشـوري الحديث تبين ان جميع البسـانين كانـت تزرع باثـجار العنب وبلـغ عدد

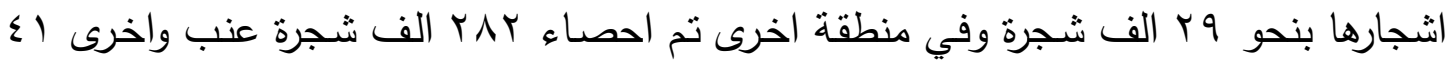
ألف شجرة عنب(09). وقد عُني الاشوريون بزراعة الكروم اذ ورد في احد نصوص سين -اخي -اريبا سنحاريب

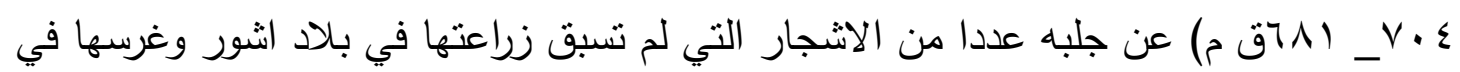
حدائقه عندالاراضي السهلية المحيطة فيها، ومما ورد في هذا النص: " وبقدرة الالهة العظيمة أصبحت الكروم والاعثاب تتمو في تلك الحقول أكثز مما كانت عليه

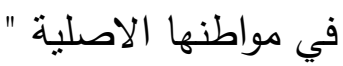

وكانت فائدة العنب الذي عرف بالسومرية GEŠTIN وبالاكدية Karánu تتركز بالدرجة الاسـاس لعمل النبيذ فضلا عن كونه من الفواكه التي أحبها سكان العراق القديم لذا اعتنوا بزراعتها (·r) وفيما يخص تسويق المشروبات ومنها النبيذ فقد اشير في النصوص الى الى الى ان عمليات بيعه كانت تتم بالجرار وليس وفق كميات خاصـة بمقاييس السوائل وبشكل عام فإن

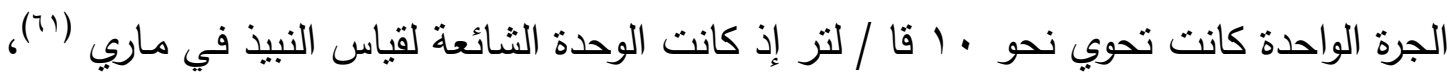
وما ذكر عن النبيذ ينطبق على مشروب الجعة الذي عرف بالاكدية sikarum بمختلف أنواعه الذي كان يحضر من الثـعير في مناطق الارياف وتتهال كميات منها الى حانات المدن في العراق القديم، ويتضح من دراسـة بعض النصوص ذات العلاقة ان اصحاب الحانات قد حصلوا على مردودات جيدة من تسويق الجعة وبيعها وقد كانت تجارتها رائجة(rآ)، ومما جاء في أحد النصوص بهذا الخصوص: 
" عسى ان يحفظلك الاله شمش ويديمك بصحة جيدة. احضر لي العطور والقصب الحلو ، واقول

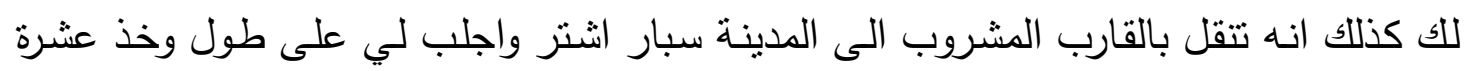

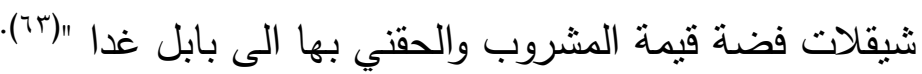

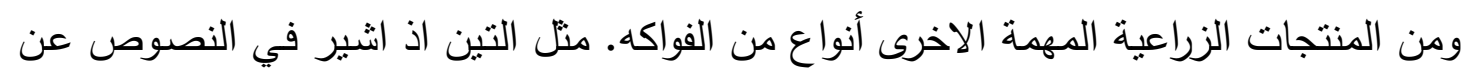

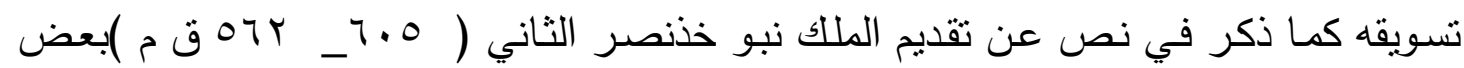
قطعه عند اداء الطقوس الدينية، وقد عرف التين في العراق منذ العصر السومري القديم، فقد ورد

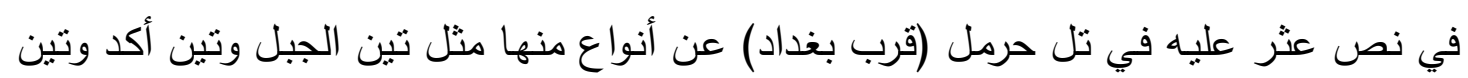

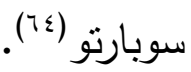

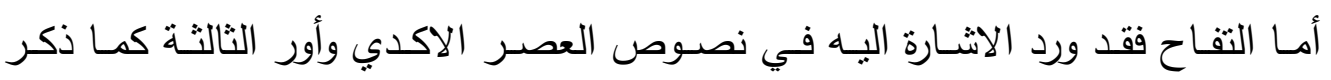
المشمش الذي عرف بتفاح الجبل مما يفهم انهم كانوا يجلبونه من المناطق الثمالية في العراق،

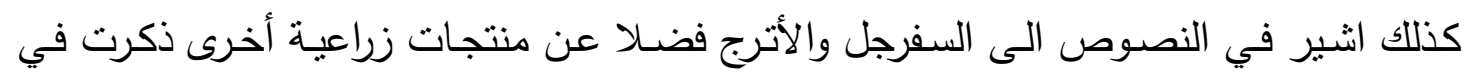
النصوص مثل الكثثري والرمان وذكر أنواع منـه الحامض والحلو والعسلي وورد عن استعمال

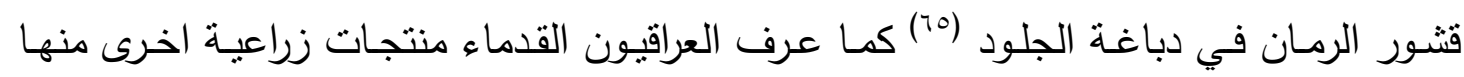
التوت والنبق منذ عصور مبكرة كما عرفوا اللفت والفجل والسلق والثثم والبصل والرشاد، فقد اثشير الثرات

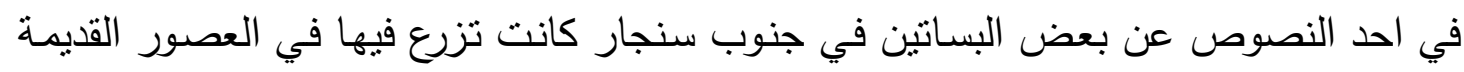

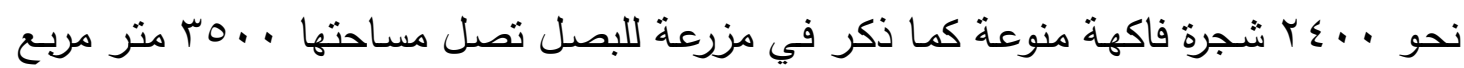

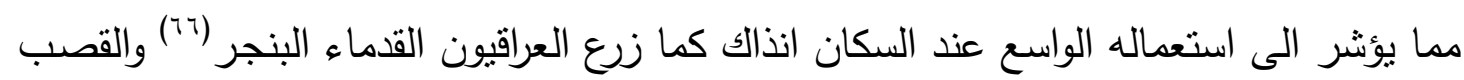

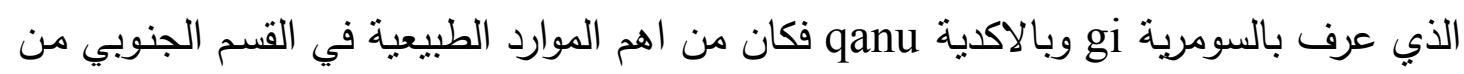
العراق من مناطق الاهوار والمستتقعات وكان للقصب فوائد عدة اذ استعمل بوصفه مادة اساسية

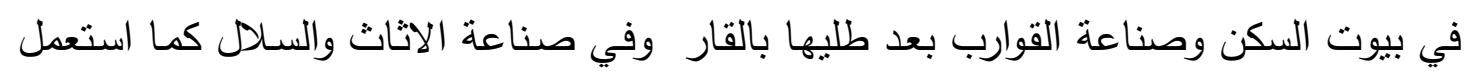

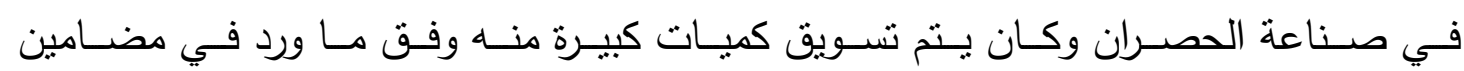
النصوص(TV) 


$$
\text { أ.د. حسين ظاهر حمود }
$$

تسويق المنتجات الزراعية بين مدن العرلق القديم

\section{جدول بالمكاييل}

المكاييل التي استخدمت لقياس مقادير الحبوب وغلات المنتجات الزراعية الأخرى،.... استتدت وحدات الكيل فيها الى المزج بين النظامين العشري والنسبي. وذلك على النحو الموضـح في

\begin{tabular}{|c|c|c|c|c|c|c|}
\hline الاسم السومرية والاكدية & المعنى & 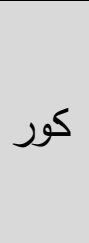 & بي & 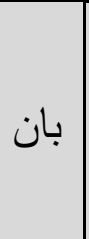 & سيلا & بالما بعادل ذللك \\
\hline GUR kurum & 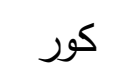 & 1 & 0 & 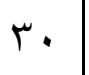 & r.. & TOY.T \\
\hline PI maššitum & بي & & 1 & 7 & 7. & $0.0 Y$ \\
\hline BAN sumum & 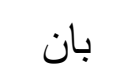 & & & 1 & $1 \cdot$ & $\Lambda . \Sigma r$ \\
\hline SILA qa & لتز & & & & 1 & $. \wedge \leqslant r$ \\
\hline BARIQA parkistu & 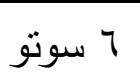 & & & & & \\
\hline imme $\quad$ immerum $^{(\uparrow \wedge)}$ & \multicolumn{6}{|c|}{ (في آثور ) حمولة حمار واحد مئة قا أو لنز } \\
\hline
\end{tabular}

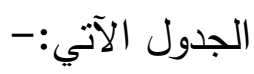

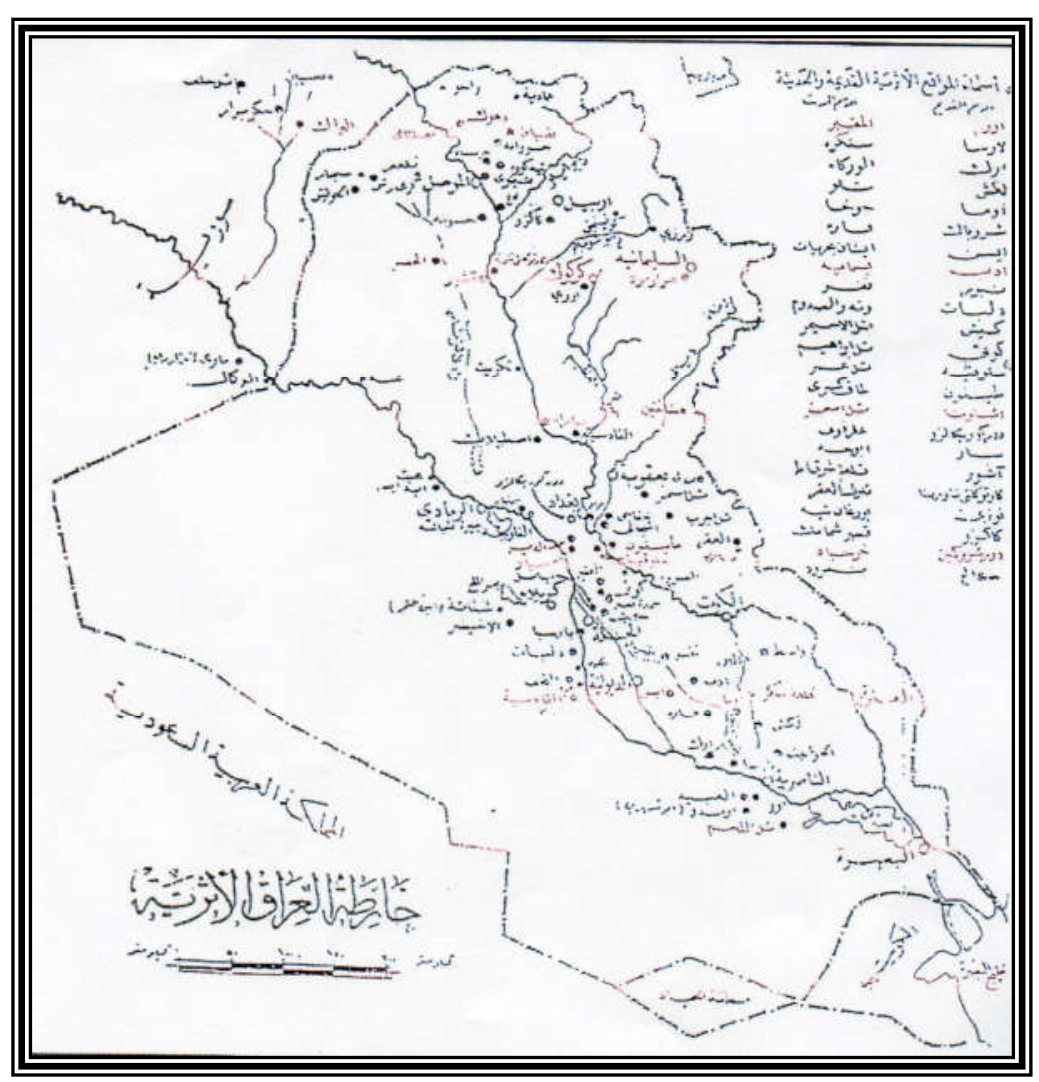

الخراطة (1) مواقع المدن القديمة والحديثة في العرلق 
1. King, Leonard, W.: A History of sumer and Akkad, London, 1916,p.6

$$
\text { - الخفف، جاسم محمد: جغرافية العراق، القاهرة، } 970 \text { 1، طب، صه ـ 1. }
$$

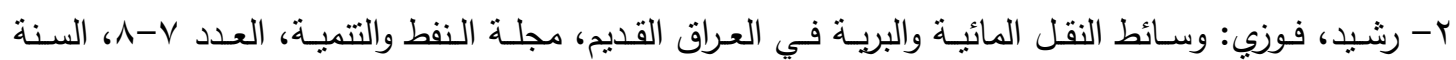

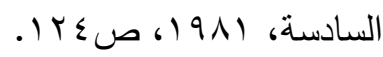

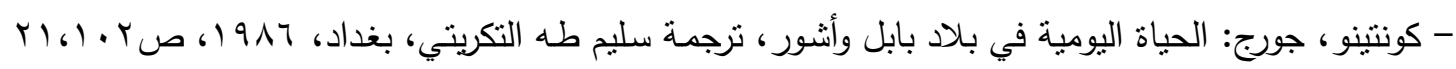

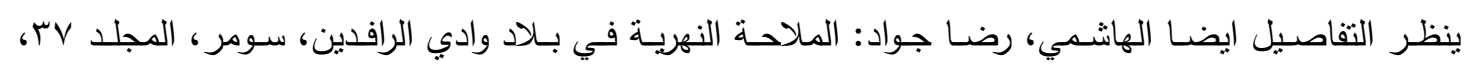

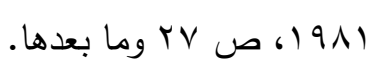

3. Mortensen,peder: on the chronology Early village farming communities in northern Iraq, sumer,Vol.18,1962,74-80

ع- حمود، حسين ظاهر : التجارة في العصر البابلي القديم، اطروحة دكتوراه غير منشورة جامعة الموصل،

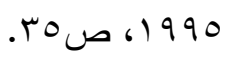

5- كسار ، اكرم عبد: مظاهر الحياة الاجتماعية والاقتصادية في العراق القديم، منذ اواخر الالف السادس ق.م

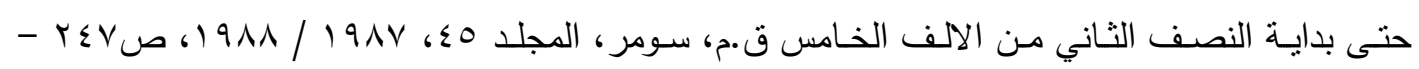

$. T \leqslant 1$

צ- حمود: المصدر السابق، ص عז.

7. Helback,hans:Early Hassuna vegetable At Es-sawwan Near samarra, sumer, vol. 20, 1964, p.47 -48،

8. Kirkbride, Daiana:Umm Dabaghiy ah 1972, Iraq, vol -35, no.1-2 1973, p.205 -209.

9. Mortensen: OP.cit,p.74 -80 .

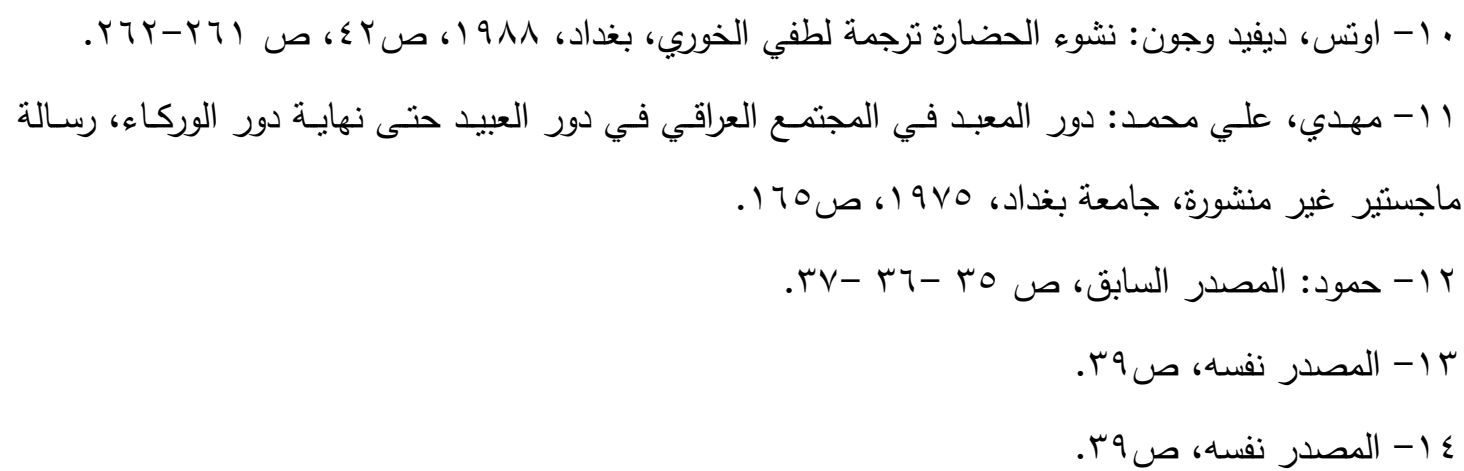

15. yaron,Reuve:the Laws of Eshnuna, 1969, p. 147,154

16. Driver G.R and Miles J.c, the Babylonion Laws,vol.1-2,1955,1960.

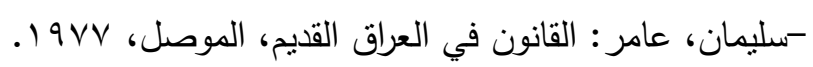

17. Leemans,w.f: old Babylonion letters and Economic History, JESHo, vol.xI,part 2,1968,p.173-177.

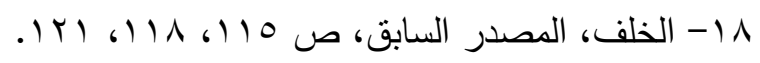




\section{أ.د. حسين ظاهر حمود

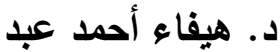

تسويق المنتجات الزراعية بين مدن العراق القديم

9 ا-المتولي، نوالـة احمد محمود: مـدخل في دراسـة الحيـاة الاقتصـادية لدولـة اور الثالثة في ضـوء الوثائق المسمارية (المنشورة غير المنشورة)، اطروحة دكتوراه منشورة جامعة بغداد، ؟99 (،ص VIV.

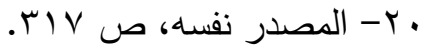

اب- بوتس، دانيال تي: حضارة وادي الرافدين: الاسس المادية، ترجمة: كاظم سعد الدين، مراجعة: إسماعيل

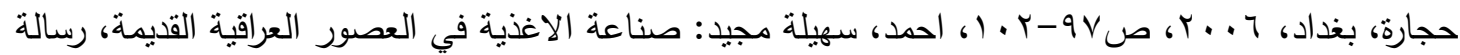
ماجستير غير منشورة جامعة الموصل، ب991)، ص | |-9 r. r r-الاحمد، سامي سعيد: الزراعة والري، في حضارة العراق جr، بغداد، 910 (، صبه 10.

23. Leemans,w.f: the Old Babylonian Business Document from ur, Bi.Or,vol.xII,No.3-4,1955,p.115-121.

24. 1bid,p.112-115

- كانت المنتجات الزراعية الجيدة تاني من الضواحي والقرى القريبة من المدن وان معظم الانتاج كان يتركز بين العوائل الفلاحية كما كانت هناك اراضي واسعة للقصر والمعبد ايضا.

- Snell,Daniel:life in the Ancient Near East, v.s. 1997,p.153.

هץ- لقد كانت مدينة نفر (نيبور) من المدن المهمة في الانتاج الزراعي في العصر البابلي القديم كما كان لها انتاجها الزراعي المميز خلال عصر سلالة اور الثالثة وكانت لهذه المدينة علاقتها المميزة اقتصاديا مع مدينة اور في مجال التسويق وهو مـا قاد الى انخفاض اسعار المنتجات الزراعية في مدينة اور بشكل خاص ، اذ علمنا ان مدينة اور كان لها دورها المميز كمطة تجارية تتوسط القنوات المائية ومنها كانت تعبر معظم السفن Snell,Ibid,p.43 على الطريق التجاري والملاحي

26. Snell,Ibid,p.134-

27. Leemans,w.f: legal and Administrative Documents of the Time of Hammurabi and Samsuiluna Leiden, 1960,p.60.

للمزيد من النصوص عن هذا الموضوع ينظر 1bid,p.80-81-

28. 1 bid,p. $-84-$

29. Dally, Stephan: Mari and Karana, London, 1984, p.84

30. Leemans,w.f:HammurapIs Babylon center of Trade, Administration and Justic, sumer, vol.xLI, No.1-2, p.93.

$$
\begin{aligned}
& \text { اس- احد: المصدر السابق، صل ا، صع؟. } \\
& \text { r r- الاحمد: المصدر السابق، ص ז7 ו-.rד } \\
& \text { ץr- حمود: المصدر السابق، ص V乏. }
\end{aligned}
$$

؟ץ- الزيباري، اكرم: نصوص من المتحف العراق " رسائل من العهد البابلي القديم " العدد الاول، بغداد، ـ97 
35. Leemans: Hammurapi's..op.cit,p.92

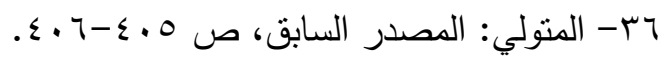

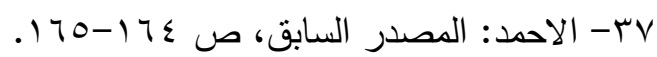

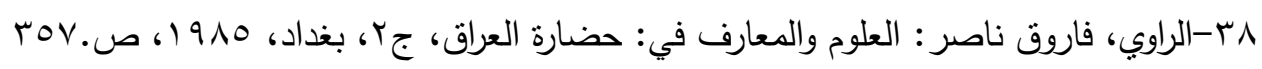

$$
\begin{aligned}
& \text { q 9-الاحمد: المصدر السابق، ص }
\end{aligned}
$$

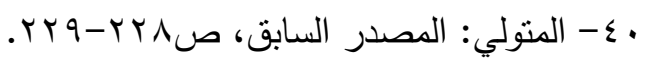

$$
\begin{aligned}
& \text { احمد: المصدر السابق، ص 197-197. } \\
& \text { اء- الاحمد: الدصدر السابق، ص } 177 \text {. } \\
& \text { المتولي: المصدر السابق، ص • بr. }
\end{aligned}
$$

42. stol,M: state and private Business in the land of larsa, Jcs, vol. 34,No.34,1982,p.132-136

$$
\text { r }
$$

44. Leemans,w.f: legal and Economic Records from the kingdom of larsa, leiden, 1954,p.29

45. Leemans: Hammurapi's..op.cit,p.92

46. Ibid, p.92

47. lerberghs,k,van: The Role of the city of Babylon...in the old Babylonian period,sumer,vol.41,1985,p.108.

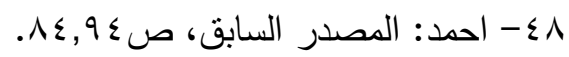

$$
\begin{aligned}
& \text { 9 - المصدر نفسه، ص99. }
\end{aligned}
$$

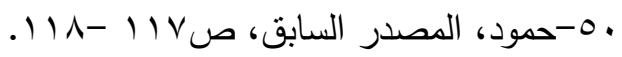

$$
\begin{aligned}
& \text { 10 - المتولي: المصدر السابق، ص بrس. } \\
& \text { احمد: المصدر السابق، ص OV - VV. } \\
& \text { r - الاحمد: المصدر السابق، ص ع 1 ا. } \\
& \text { rه - احمد: المصدر السابق، ص هV--.A. } \\
& \text { ــ- حمود: المصدر السابق، ص 9؟. } \\
& \text { 00- بوتس: المصدر السابق، ص بr T. } \\
& \text { T- احمد: المصدر السابق، ص VV. }
\end{aligned}
$$

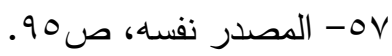

$$
\begin{aligned}
& \text { 101- الاحمد: الدصدر السابق، ص } 10 \text { 1. } \\
& \text { 09- المصدر نفسه، ص } 170 .
\end{aligned}
$$

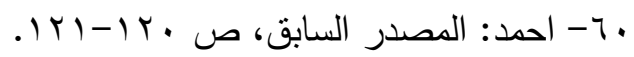


د. ديفاء أحمد عبد

$$
\begin{aligned}
& \text { المتولي: المصدر السابق، ص سـ } \\
& \text { آ- بوتس: المصدر السابق، ص Or Y. } \\
& \text { ז7- حمود: المصدر السابق، ص } 01 .
\end{aligned}
$$

63. Oppenheim: Letters from Mesopotamia, London, 1984,p.83.

ـ ؟- الاحمد: المصدر السابق، ص 170.

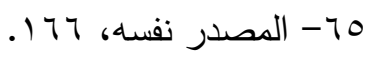

177- المصدر نفسه، ص 170

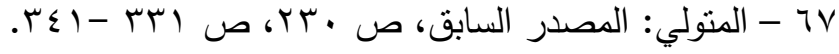

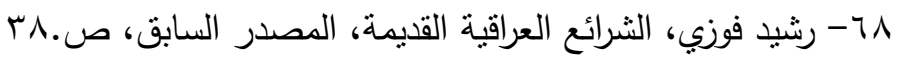

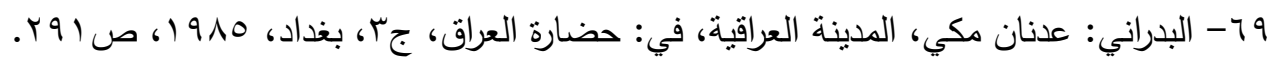





\section{Journal}

\section{AL- Rafedain Archaeology}

Accredited Scientific Journal

It Search's in Archaeology of Iraq and Ancient Near East

Published by College of Archaeology - University of Mosul

$$
\text { E_Mail:ali_aljuboori@yahoo.com }
$$



